\section{Do público ao privado: a transição do modelo de negócios ferroviários no Brasil 1930- 2015}

\author{
(1vanil Nunes \\ Faculdade Campos Elíseos, Universidade Federal do Estado de São Paulo, Brasil.
}

Recebido: 2 de abril de 2018. Aceptado: 1 de octubre de 2018.

\begin{abstract}
Resumen
O sistema ferroviário brasileiro é marcado precocemente pela presença estatal que ora intervém diretamente, ora indiretamente, ao longo das seis fases aqui consideradas. $\mathrm{Na}$ última delas prevaleceu uma estrutura privada. O objetivo neste trabalho é analisar três destas fases, a partir de 1931, quando o Estado passou a se apropriar destas empresas; a modificá-las estruturalmente (entre 1961-1991); e a devolvê-las à iniciativa privada a partir de 1991. Momento a partir do qual estavam aptas a exercer novas funções: a de atender a um seleto grupo de clientes e de seus respectivos produtos, empregando um mínimo de trabalhadores. As linhas entregues à 'privatização' na década de 1990 eram completamente distintas daquelas deficitárias, que foram estatizadas na década de 1940 e 1950. Após quatro décadas de intervenção estatal direta as ferrovias haviam sido reinventadas, passando a operar abaixo de outra lógica: a de "ferrovia-mínima", que acabou por reestimular os empresários privados a voltarem ao setor!
\end{abstract}

\section{From the public to the private: the transition of the railway business model in Brazil 1930 to 2015}

\section{Palavras-chave}

Ferrovias

Estatização

Modelo de negócios

Ferroviários

\begin{abstract}
The Brazilian railway system is marked early by the state presence that now intervenes directly, or indirectly, throughout the six phases considered here. In the last of them a private structure prevailed. The objective of this study is to analyze three of these phases, starting in 1931, when the state started to appropriate these companies; to modify them structurally (between 1961-1991); and to return them to the private sector from 1991 onwards. At that time, they were able to perform new functions: to serve a select group of customers and their respective products, employing a minimum number of workers. The lines delivered to 'privatization' in the 1990s were completely different from the deficit lines, which were nationalized in the 1940s and 1950s. After four decades of direct state intervention, the railways had been reinvented, operating under another logic: "Minimal railroad", which eventually restimulated private entrepreneurs to return to the sector!
\end{abstract}

\section{Key-words}

Railways Nationalization Business model Workforce

Palabras clave

Ferrocarriles Estatización Modelo de negocio Ferroviarios

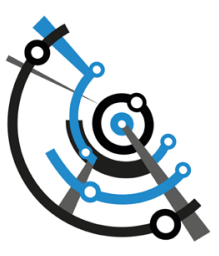




\section{Introdução}

O objetivo neste trabalho é traçar um panorama histórico geral do funcionamento do sistema ferroviário brasileiro a partir de uma perspectiva revisionista; a de que este sistema não foi desmontado de modo generalizado -como afirma a historiografia tradicional- mas sim, reinventado a partir de intervenção estatal.

O desenvolvimento ferroviário brasileiro desde seu início esteve intimamente ligado a políticas de Estado e de governo, que variaram bastante ao longo da história, ao longo de distintas fases. A título de contextualização considera-se aqui como fases da evolução do sistema ferroviário as, basicamente, mesmas seis adotadas pela Associação Nacional dos Transportadores Ferroviários (ANTF), a saber: Fase I (1835 - 1873): ocorrida durante a Regência e o Segundo Reinado, em que se observa o início da implantação de ferrovias no Brasil e o desenvolvimento desse sistema de transportes de forma lenta, conduzido por empresas majoritariamente privadas; Fase II (1873 - 1889): que abrange o Segundo Reinado e se caracteriza por uma expansão acelerada da malha ferroviária, através de empreendedores privados, estimulados pelo instituto da garantia de juros; Fase III (1889 - 1930): em que se engloba a República Velha, período em que se observa um último surto de expansão da malha, porém, com a particularidade de que o Estado passa a exercer o controle de várias empresas em dificuldades financeiras; Fase IV (1931 - 1961): em que se compreende o governo Vargas e o pós-guerra, quando o ritmo de expansão diminui substancialmente e o controle estatal das empresas antes privadas passa a ser quase total; Fase V (1961 - 1990): situada quase que inteiramente ao longo do governo civil-militar, momento em que a totalidade das empresas férreas foi operada por empresas estatais (RFFSA, FEPASA, EFVM ${ }^{1}$ ), em um cenário de erradicação de ramais antieconômicos e desativação de serviços deficitários; as novas linhas, quando implantadas neste período, se limitaram a projetos seletivos de caráter estratégico, como fora o caso da pequena Estrada de Ferro Trombetas, concedida em 1978 a VALE, utilizada para o transporte de bauxita, no estado do Pará, e da Estrada de Ferro Carajás (EFC), fundada em 1985, especializada no transporte de minérios, também da Vale, do Pará ao Maranhão; e, por último, a Fase VI (1990 - atual): período da Nova República, marcado pela privatização de todo o sistema ferroviário nacional (ANTF).

Vale apontar que o sistema ferroviário brasileiro foi constituído por diversas empresas, localizadas em partes específicas do território, que ao longo de anos atenderam a propósitos diversos. Esse conjunto de ferrovias brasileiras (inauguradas na segunda metade do século XIX), e distintas entre si, apresenta um histórico comum marcado pela expansão das linhas e dos transportes; redução do saldo operacional (e na maioria dos casos, por prejuízos crescentes); pela completa estatização do setor (no pós-Segunda Guerra Mundial), e posterior desestatização, na década de 1990.

Inicialmente sob a condução majoritariamente privada esta malha foi retomada pelo Estado - fenômeno que se ampliou a partir do primeiro governo Vargas (1930-1945) e que se concluiu na fase seguinte, quando ocorreu a estatização total do sistema (entre 1948 e 1961). Sob controle estatal estas empresas foram submetidas a um longo processo de reinvenção do modelo de negócios ferroviários no Brasil, de tal modo exitoso, que estimulou, de novo, na década de 1990 (tal qual havia ocorrido no século XIX) à volta de investidores privados ao setor.

Diversos autores brasileiros argumentam que a partir da década de 1940 as ferrovias brasileiras teriam entrado em decadência e por este motivo teria ocorrido o "Fim da era ferroviária”. É há razões para que assim o façam. Ao final da década de 1940,

Rede Ferroviária Federal; Ferrovia Paulista SA; e, Estrada de Ferro Vitória a Minas 
quase a totalidade das ferrovias brasileiras já estavam estatizadas e a maior parte das linhas era administrada pelo governo federal ou por alguns poucos governos estaduais. Diante deste quadro é que diversos pesquisadores, diante desta falência generalizada das empresas do setor ferroviário, acabaram por deduzir que o sistema ferroviário brasileiro havia chegado ao fim. De acordo com suas conclusões, o país teria entrado na era rodoviária de tal modo que as novas perspectivas para o seu desenvolvimento, passariam a ocorrer notadamente por meio de articulação deste modal, enquanto as ferrovias estariam relegadas ao abandono.

Dentre os principais defensores desta argumentação central e suas variantes destacam-se - à frente - Odilon Nogueira de Matos (1990) além de Mivaldo Messias Ferrari (1981), Flávio Azevedo Marques de Saes (1981), Chafic Jacob (1982) e Helena Maria A. Capelini (1986). Segundo Matos (1990:166), nos estados do Rio de Janeiro, São Paulo e até mesmo em outras regiões, a estrada de ferro surgiu "intimamente ligada ao café" de forma que "toda a rede ferroviária, com raras exceções, foi construída em função do crescimento da cultura cafeeira", em um processo de expansão cuja vigência teria ocorrido entre 1852-1940, quando teriam se consolidado alguns dos aspectos fundamentais da história econômica e social de São Paulo.

(...) superado o fundamento econômico que as motivou, pela natural itinerância do café, ou por decorrência de fatores externos que condicionaram o apelo às rodovias, elas [as ferrovias] tenham se tornado antieconômicas praticamente sem função em muitos de seus trechos, que acabaram sendo suprimidas. Não tendo sido reaparelhadas para novas funções e não tendo condições para resistir à concorrência das rodovias, acabaram muitas delas se tornando obsoletas, entravando o desenvolvimento das regiões, justificando, enfim, a supressão autorizada pela Lei n.2698, de 27 dez. 1955. (...) Eis por que julgamos oportuno deter nosso trabalho em 1940, data em que tomamos como limite final da era ferroviária (idem, 1990:167-8).

Importante destacar aqui que Matos analisa apenas e tão somente às ferrovias localizadas em São Paulo. No entanto, como este autor não especifica quais eram esses "trechos" suprimíveis, nem quais eram as "muitas delas" que se tornaram obsoletas, isso parece ter contribuído para a disseminação de uma explicação generalizante, que acabou por se confundir a parte com o todo. A título de justiça, vale explicitar o óbvio que Matos é responsável apenas pelo que ele escreveu e não pelo que alguns de seus leitores parecem ter entendido; pois grande parte da argumentação de Matos foi utilizada por Jacob, Capelini, Ferrari e outros para justificar ou insinuar o "fim da era ferroviária", no Brasil, a partir da década de 1940.

Afinal, teriam as ferrovias brasileiras passadas por um desmonte generalizado devido à intervenção estatal no setor ferroviário a partir do governo Vargas? Ou será que o Estado brasileiro ao retomar estas empresas, operou na verdade, a uma reinvenção do modelo de negócios ferroviários?

Argumenta-se distintamente neste artigo que, entre 1961 e 1991, não ocorreu um fim ou desmonte generalizado dos serviços ferroviários, ou o abandono deste setor, ao ponto de levá-lo a um final. Ao contrário, a hipótese central aqui defendida é que elas foram, sim, "reaparelhadas para (atender a) novas funções". Na verdade, foi o modelo de negócios ferroviários, vigente no Brasil desde o século XIX (baseado no conceito de "produção múltipla"), que passou por um longo processo de transição marcado pela redução e/ou eliminação daqueles serviços não relacionados ao transporte de cargas, tais como o de passageiros, bagagens e encomendas, e animais. Nesta linha argumentativa, sustenta-se que esta reinvenção do modelo de 
negócios ferroviários foi patrocinada pelo Estado (em âmbito federal e estadual), que muito investiu (em fator capital), possibilitando a redução do uso da mão de obra; combinação esta, que resultou em aumento da produtividade e estimulou a volta de investidores privados ao setor.

Portanto, o modelo de negócios iniciado no século XIX chegou ao fim em 1961, com a privatização da última grande empresa ferroviária privada em operação: a Companhia Paulista. A partir deste período o setor passou por uma longa fase transição, que se encerrou no começo da década de 1990, durante os governos durante os governos Fernando Collor de Melo e de Fernando Henrique Cardoso. O início da década de 1990 marcaria, então, a fase final daquele antigo modelo, pois a partir daí seria radicalmente alterada a forma de funcionamento do sistema ferroviário nacional, cuja característica principal passou a ser a redução do uso da mão de obra combinada à especialização em transportes de cargas, o que resultou em crescente aumento da produtividade média das linhas que restaram em operação no país.

Ao longo da década de 1990 foi se conformando um novo modelo de negócios ferroviários ao qual se pode denominar 'ferrovia-mínima'. Neste novo formato a força de trabalho ferroviária foi reduzida ao mínimo. Também os clientes destas operadoras, cada vez mais especializadas em transportes de cargas (em detrimento de outros serviços), foram reduzidos a um seleto grupo de usuários - grandes usuários; que já vinham desde antes 'privatizando', como demandantes privilegiados, os serviços ferroviários. O modelo de desestatização, iniciado no governo Collor, reconheceu como de direito e potencializou práticas que já vinham ocorrendo no mercado de transportes ferroviários. Foi este modelo, 'ferrovia-mínima', instituído anteriormente à desestatização, que serviu de parâmetro para se reordenar o setor com base nos fundamentos legais instituídos pelo Programa Nacional de Desestatização, cujos objetivos explícitos eram "reordenar a posição estratégica do Estado na economia transferindo à iniciativa privada atividades indevidamente exploradas pelo setor público" (BRASIL (a) 1990).

Desse modo, o sistema ferroviário brasileiro, nas últimas décadas foi deixando de corresponder à sua condição de serviço público, que atendia a diversos setores e localidades dentro do país, para uma condição em que seu uso passou a ser cada vez mais privado.

Este artigo está organizado em três partes principais, além desta introdução e das considerações finais. Na primeira, se contextualiza o processo de passagem da operação ferroviária para o controle estatal, compreendida especialmente entre o início do governo Vargas e a década de 1950. Na segunda se analisa a longa fase de transição da RFFSA, ocorrida entre 1961 e 1991, em que o Estado reinventou o modelo de negócios ferroviários no Brasil, por meio da redução da oferta de alguns de seus serviços, combinada com a desativação de linhas e serviços; o que implicou em menor demanda por empregados; logo em diminuição de custos que reduziriam parcialmente os déficits e ampliação dos ganhos, em produtividade. $\mathrm{Na}$ terceira, analisam-se as ferrovias-mínimas no Brasil a partir da década de 1990, onde se busca explicar o processo de consolidação e as características deste novo modelo de negócios ferroviários estabelecido no Brasil a partir da década de 1990; momento a partir do qual o setor ferroviário nacional deixou para trás, de fato e de direito, o antigo padrão de funcionamento que vigia desde o século XIX. 


\section{O começo do fim do modelo de negócios ferroviários, 1930-1961}

De acordo com Bogart (2009:202), em diversas partes do mundo, ocorreu desde a segunda metade do século XIX, a um crescente processo de nacionalização de empresas ferroviárias. O autor detecta que entre 1860 e 1913, por exemplo, este fenômeno já havia ocorrido em distintos países como a Rússia, Suécia, Dinamarca, Holanda, Bélgica, França, Suíça, Itália, Áustria, Hungria, Bulgária, Sérvia, Japão, México, Costa Rica, Brasil, Argentina, Alemanha, Índia, Austrália, e Nova Zelândia. Em conjunto, os 35 países ou colônias analisadas por Bogart teriam nacionalizados mais de cinquenta mil milhas (aproximadamente oitenta mil quilômetros) ou algo como $10 \%$ do total das linhas construídas em 1910.

É claro que estas estatizações não ocorreram pelos mesmos motivos. Em alguns casos, os estados expropriaram os ativos de várias empresas privadas por meio de leis ou decretos, e em outros casos, o estado adquiriu ferrovias individuais que estavam falidas ou em dificuldades. Em função do objetivo deste trabalho, não serão analisadas aqui as causas que levaram cada uma destas empresas à estatização - pois, para tanto haveria de se elaborar um trabalho específico. Embora se considere os riscos de generalizações neste caso, parece razoável se considerar, como o faz Bogart, que as nacionalizações foram impulsionadas pelo fraco desempenho financeiro das ferrovias privadas combinado a vários fatores, dentre estes a concorrência ruinosa, baixa demanda, altos custos operacionais e interferências políticas - diante de um mercado em que o Estado teve, desde o início, enorme poder para facilitar (ou dificultar) a operação privada, ou a faculdade de desapropriar estas mesmas empresas.

A Estrada de Ferro D. Pedro II, por exemplo, foi concebida por meio de um primeiro decreto expedido no Brasil com vistas a garantir privilégios, por 40 anos, para que investidores privados instalassem as linhas férreas ligando o Rio de Janeiro a Minas, Rio Grande do Sul e Bahia. Inaugurada em 7 de agosto de 1864 foi encampada em 1865. Ao passar ao domínio estatal a companhia media 137 quilômetros (ESTRADA DE FERRO D. PEDRO II, 1880:8). Depois da estatização, a empresa entrou em um ciclo de expansão de suas linhas para aproximadamente 3.500 quilômetros. Por meio da utilização de recursos públicos chegou a São Paulo (1875), Belo Horizonte (1895) e ampliou suas linhas no Rio de Janeiro (GUIA GERAL DAS ESTRADAS DE FERRO).

Voltando ao fato relevante, que aqui se destaca, por volta de 1870 a operação ferroviária privada, na maior parte dos países, correspondia a cerca de $90 \%$ das linhas em operação. Em 1912, no entanto, as empresas estatizadas deste setor já correspondiam a cerca de $30 \%$ de toda a malha férrea mundial e cerca de $20 \%$ destas linhas havia sido instaladas pelos Estados, que as administravam diretamente ou as arrendavam a terceiros. As estatizações, em geral, seriam controversas: "because they represented an abrupt change in policy, and in some cases a violation of private property rights. They also touched upon deep political divisions within societies" (Bogart, 2009:203).

No Brasil, em 1913, de um total de 24.614 km de vias em operação no país, 12.773 $\mathrm{km}$ pertenciam à União (Federação) enquanto os outros $48 \%$ de vias eram exploradas basicamente por empresas particulares. 


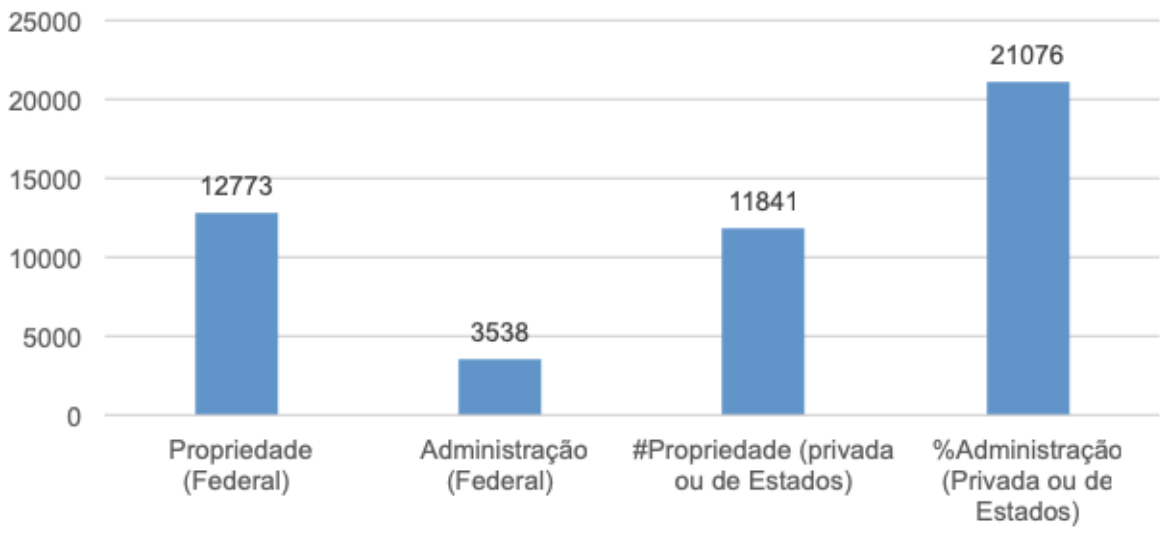

Figura 1. BRASIL. Linhas férreas em operação: por tipo de propriedade ou administração. Fonte: BRASIL, MVOP, 1915: XXXVI.

No entanto, a União administrava, diretamente, apenas $14,4 \%$ destas linhas, enquanto $85,6 \%$ das linhas férreas do país eram administradas majoritariamente por operadores privados. Em termos absolutos, a União conseguia transferir para outros por meio de arrendamento $9.235 \mathrm{~km}$ de linhas - ou, $72 \%$ de suas linhas.

Em 1922, de um total de $29.341 \mathrm{~km}$ de vias férreas, a União era proprietária de 17.363 $\mathrm{km}$, equivalente a $59 \%$, porém, administrava diretamente $8.917 \mathrm{~km}$, equivalente a $30 \%$ das linhas totais. O que vale dizer que a União conseguia ofertar para outros operarem, por meio de arrendamento, $8.446 \mathrm{~km}$ (ou quase a metade de suas linhas). No entanto, vale observar, que, proporcionalmente, o total de linhas operadas diretamente pela União havia dobrado neste período: de $14 \%$ para $30 \%$ do total o que indica que a União vinha crescendo em participação de mercado, por meio da operação direta dos transportes ferroviários (Brasil, MVOP, nd: XLIX).

As linhas de propriedade privadas, que mediam cerca de 10 mil quilômetros, representavam apenas $34,4 \%$ do total em operação no país; embora, os concessionários privados operassem cerca de $50 \%$ das linhas férreas do país: as deles e as arrendadas junto à União ou Estados. De propriedade dos estados da federação e por eles administrados se contavam cerca de 1.800 quilômetros de vias e tal qual ocorria com os operadores privados, os estados também arrendavam linhas da União; naquela ocasião, a quase 4 mil quilômetros de vias, o que totalizava aproximadamente $20 \%$ das linhas férreas brasileiras sob gestão dos estados (idem). De onde se conclui que 50\% das linhas eram administradas por operadores privados e a outra metade pelo setor público (União mais estados).

No entanto, esse crescimento da participação da União no mercado de transportes ferroviários começou a se ampliar substancialmente a partir da Primeira Guerra Mundial; 


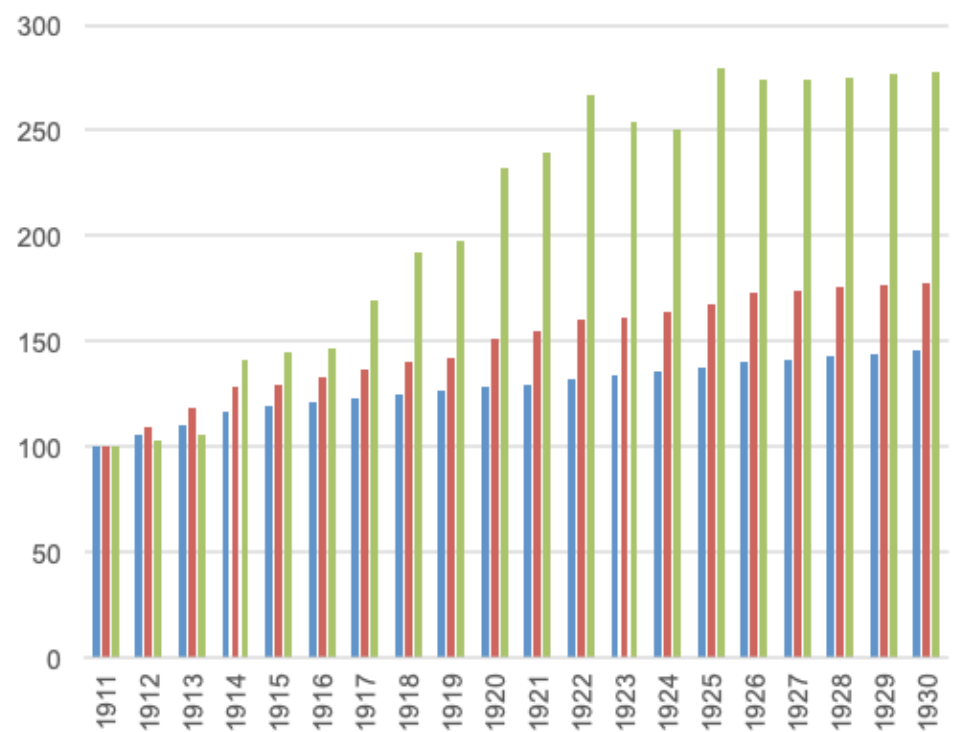

Figura 2. Evolução comparativa das linhas: totais; de propriedade da União; e, administradas pela União. 1911 a 1930 (ano base 1911 = 100). Fonte: BRASIL, MVOP.

Tomando-se o ano de 1911 como base se verifica que a expansão da malha férrea nacional cresceu $24 \%$ entre 1911 e 1918; no mesmo período as linhas de propriedade da União cresceram em torno de 40\%; no entanto, o total de quilômetros de linhas operadas diretamente pela União quase dobrou passando de $3.300 \mathrm{~km}$ para 6.400 (Brasil, MVOP). E, ao longo da década de 1920, a União seguiu ampliando sua participação; em 1925, por exemplo, embora fosse proprietária de 18 mil quilômetros de vias, a União operava mais da metade destas linhas $(9.353 \mathrm{~km})$. O que na prática significou um encolhimento da participação do operador privado diante da retomada cada vez maior de linhas por parte do setor público e perante a menor disposição de operadores privados em arrendar aquelas linhas estatais. Em outros termos, na ausência do arrendatário privado, era o setor público que se via obrigado a operá-las.

Conforme indicam os dados esse fenômeno, de saída do operador privado, se tornará cada vez mais visível a partir de 1934, em um momento em que mercado era formado por 56 empresas: vinte e três privadas, e trinta e duas empresas públicas. ${ }^{2}$

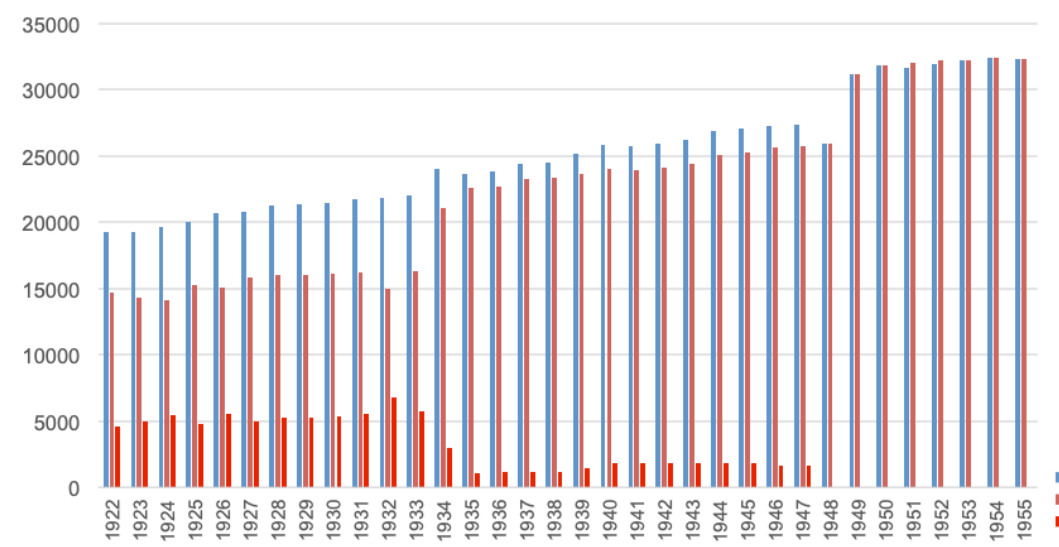

2. Particulares: E. F. Leopoldina, E. F. Victória a Minas, E. F. Santos a Jundiahy, E. F. Mogiana, E. F. Corcovado, São Paulo Railway, Companhia Paulista de Estradas de Ferro, E. F. Ilhéus a Conquista, E. F. Morro Velho, E. F. do Dourado, E. F. São Paulo Goyaz, E. F. Morro Agudo, E. F. São Paulo-Minas, E. F. Itatibense, Ramal Férreo Campineiro, E. F. do Monte Alto, Ramal Férreo Dumont, E. F. São Paulo-Paraná, E. F. Barra Bonita, E. F. do Norte do Paraná, E. F. Mate-Laranjeira, E. F. Jaboticabal, E. F. Perus-Pirapora. Administradas pela Uniẫo: E. F. Central do Brasil, E. F. Noroeste do Brasil, Rede Paraná - Santa Catarina, Rede de Viação Cearense, Viação Férrea Federal do Leste Brasileiro, Estrada de Ferro Tocantins, E. F. São Luiz-Teresina, E. F. Central do Piauhy, E. F. do Rio Grande do Norte, E. F. Petrolina - Therezina, E. F. Maricá, E. F. de Goyaz; 2) Arrendada aos Estados: Rede Mineira de Viação, Viação Férrea do Rio Grande do Sul , E. F. Bragança, E. F. Santa Catarina; 3) Arrendadas a particulares: Great Western of Brazil, E. F. Madeira - Mamoré, E. F. Mossoró, E. F. D. Tereza Christina, E. F. Jacuhy. Pertencentes aos Estados. 1. Bahia: E. F. Nazaré e E. F. Santo Amaro; 2. Espírito Santo: E. F. Benevente e Alfredo Chaves, E. F. Itapemirim, E. F. São Matheus; 3. Minas Gerais: E. F. Trespontana; 4. Paraná: E. F. do Litoral; 5. Rio Grande do Sul: E. F. Palmares a Conceição do Arroio, E. F. Porto Alegre a Tristeza; 6. São Paulo: E. F. Araraquara; E. F. Campos do Jordão, E. F. Machadense, E. F. Sorocabana e Tramway da Cantareira (Brasil, MVOP, 1936:15).

Figura 3. BRASIL. Linhas estatizadas (em $\mathrm{km}$ ) e suas respectivas formas de operação: pública ou privada, 1922 a 1955. Fonte: BRASIL, MVOP, diversos anos. 
Conforme se pôde observar no Figura 3, a expansão das linhas que vão se incorporando à propriedade da União tenderam a aumentar. De uma média de 21 mil quilômetros entre 1922 e 1934 para uma média de quase 26 mil quilômetros no período 1935 a 1947. Em 1949, quase a totalidade das linhas ( $87 \%$ do total em operação) pertencia à União ou aos estados (idem).

Até 1933, quando o setor público (União ou estados) ainda conseguia encontrar operadores privados interessados em arrendar parte de suas linhas havia em média 5.350 quilômetros de vias sob arrendamento. A partir de 1934 e até 1947 os arrendatários privados administravam apenas 1.600 quilômetros de vias de propriedade estatal; e, a partir de 1948 passou a não mais existir operadores privados interessados em arrendar linhas públicas (estatizadas); assim, coube ao Estado (União ou estados) administrar diretamente aquelas vias que vinham recebendo de volta, há anos - e que demandavam altos investimentos em locomotivas, carros, vagões, trilhos, renovação de processos, etc. diante de um quadro de déficit crescente, em que a receita era incompatível com os custos operacionais do conjunto das empresas férreas que vieram a formar à RFFSA. O que se percebe é que em 1945 a receita obtida pelo conjunto de empresas que vieram a compor a RFFSA estava na fronteira do déficit, quando os custos com salários e despesas equiparavam à receita total. No ano seguinte, as despesas já superavam a receita em 18\%. No ano de formação da RFFSA (1957) as despesas já eram 112\% maiores que a receita da nova companhia.

A dificuldade em majorar as tarifas na mesma proporção do aumento de seus custos, em um cenário em que os trabalhadores passaram a ter liberdade sindical, após anos de ditadura (Estado Novo), e que passaram a lutar por maiores salários, fazia com que os custos salariais passassem a subir relativamente mais a partir de 1948. E vale se destacar, que não se pode aqui imputar apressadamente o argumento de que estava ocorrendo empreguismo (ou excesso de trabalhadores) na RFFSA. No mesmo período, a quantidade de trabalhadores foi aumentada de aproximadamente 130 mil para 154 mil ferroviários enquanto a produção, medida em Unidades de Tráfego [Transporte de Passageiros (interior e subúrbio); de bagagens e encomendas; de animais e de mercadorias] cresceu mais de $100 \%$; especialmente após a formação da RFFSA; entre 1957 e 1963 a quantidade de passageiros transportados pelos subúrbios operados por aquela companhia cresceu $83 \%$, enquanto o transporte de mercadorias cresceu quase 90\% (RFFSA, 1963; 1965); o que demonstra, fartamente, que estava ocorrendo um enorme aumento de produtividade média da mão de obra naquela empresa, neste período apontado, em função de forte investimentos que vinham sendo realizados pelo governo federal (RFFSA, 1963:4).

No entanto, em 1952, as despesas salariais já equivaliam à toda a receita arrecadada pela RFFSA; em 1962, a receita da companhia era suficiente para pagar apenas a metade da massa salarial devida pela empresa. 


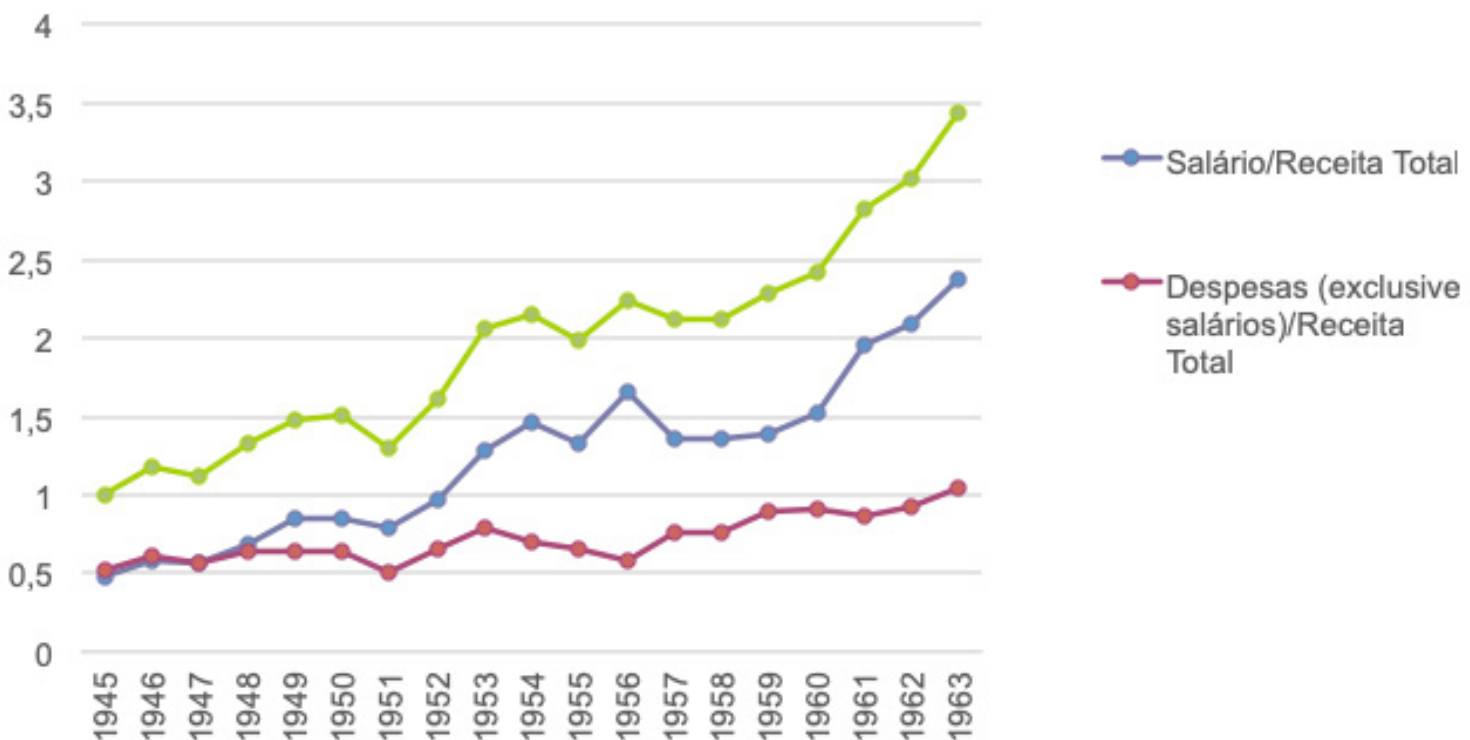

Figura 4. RFFSA. Evolução comparativa entre Receitas e despesas: salariais e outras, 1945 a 1963. Fonte: RFFSA. Anuário Estatístico da RFFSA.

Parece visível o descompasso entre a expansão dos transportes e o déficit crescente o que só demonstra a necessidade de se aprofundar a discussão acerca do suposto populismo (ou empreguismo) apontado por Cipollari et al. (1978:54). ${ }^{3}$

3. Sobre esta discussão, ver Nunes (2017).

A partir de 1949, restavam em operação sob a propriedade privada apenas nove empresas: A Morro Velho, Companhia E. F. Mossoró, Estrada de Ferro Vitória a Minas, Itabapoana, Corcovado, Companhia Paulista (nesta contidas as recém adquiridas estradas de ferro: Dourado, São Paulo-Goiás, Barra Bonita, Jaboticabal, e Morro Agudo) a Cia. Mogiana, Votorantim e Perus-Pirapora (BRASIL, MVOP, 1956:17).

Dois fatos merecem destaques em relação à reorganização do sistema ferroviário nacional a partir de 1949: um sob a ótica estatal e outra sob a perspectiva privada. O Estado, em âmbito nacional passou assumir o papel de empresário e regulador do setor. Como regulador, a União constituiu uma empresa, a Rede Ferroviária Federal (RFFSA), entre 1953 e 1957, que teve como missão unificar sob seu controle as linhas que haviam sido estatizadas até então sob as orientações oficialmente defendidas pelo Estado brasileiro, a saber:

Fiscalizar, em todo o território nacional, os serviços de transporte ferroviário; promover a coordenação de estudos tarifários e de custos de transportes ferroviários em geral; planejar a unificação e padronização do sistema ferroviário brasileiro; proceder à avaliação qualitativa e quantitativa do sistema ferroviário nacional; realizar pesquisa relacionada com o aperfeiçoamento das atividades ferroviárias no País; e proceder à execução da parte ferroviária do Plano Nacional de Viação (BRASIL, 1957).

Como empresário a União, com a RFFSA à frente, passou a adotar uma postura de desmonte parcial daquelas linhas consideradas antieconômicas. O que na prática já vinha ocorrendo desde a aplicação da Lei n. 2.698, de 27 de dezembro de 1955, que por meio da arrecadação de $30 \%$ (trinta por cento), da receita proveniente da diferença de preços entre os combustíveis e lubrificantes líquidos derivados do petróleo fabricados no Brasil e importados, passou a determinar a aplicação deste recurso à construção, revestimento ou pavimentação de rodovias destinadas a substituir ramais ferroviários reconhecidamente deficitários. A partir da vigência 
desta lei, os Departamentos Nacionais de Estradas de Rodagem e Estradas de Ferro, em trabalho conjunto, passaram a eleger os trechos ferroviários que seriam substituídos por estradas de rodagem (BRASIL, 1955).

Conforme se pode verificar, a erradicação de linhas passou a ser uma prática comum no Brasil, ao longo da década de 1960.

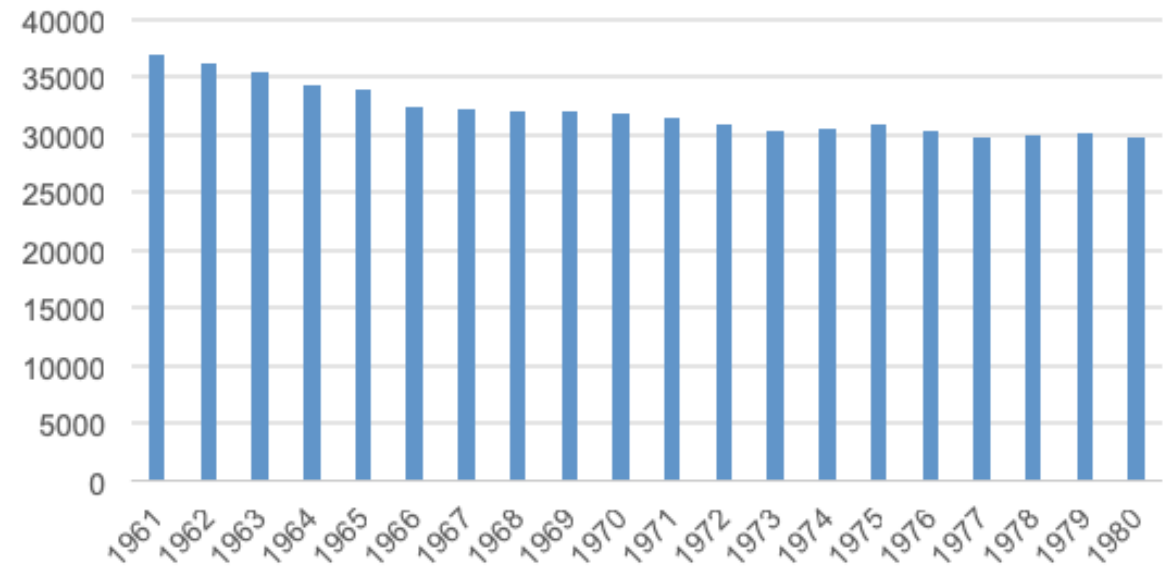

Figura 5. BRASIL. Erradicação de linhas (em km) consideradas antieconômicas. Fonte: RFFSA. Anuário Estatístico da RFFSA.

O que se verifica é que entre 1961 e 1965 quase 10\% das linhas em operação já haviam sido desativadas; outro tanto recebeu o mesmo tratamento ao longo dos anos seguintes; ao todo foram retirados pelo menos sete mil quilômetros de vias.

No estado de São Paulo, estas linhas remanescentes foram reunidas em uma só empresa estatal: a Ferrovia Paulista SA (FEPASA), constituída em 10 de novembro de 1971, ${ }^{4}$ quando passaram a operar sob uma mesma administração as empresas antes estatizadas naquele estado, tais como E.F. Sorocabana (1919), E.F. Araraquara (1919), e E.F. São Paulo Minas (1931), a Companhia Mogiana de Estradas de Ferro, (1952) e a Companhia Paulista, em 1961.

Com a estatização da Paulista chega-se ao fim aquele modelo de negócios iniciado no século XIX. A partir deste período o setor passou por uma longa fase transição, que se encerrou no começo da década de 1990, durante os governos Fernando Collor de Melo e de Fernando Henrique Cardoso. ${ }^{5}$ O início da década de 1990 marcaria, então, a fase final daquele antigo modelo, pois a partir daí seria radicalmente alterada a forma de funcionamento do sistema ferroviário nacional, cuja característica principal passou a ser "mais do mesmo": redução do uso de mão de obra, devido à especialização das ferrovias nos transportes de cargas, que resultou em crescente aumento da produtividade média do setor.

\section{A transição rumo ao novo modelo de negócios, 1961-1991}

A partir do golpe civil-militar, de 1964, a redução do papel da RFFSA no mercado de transportes ficou ainda mais evidente quando a empresa passou a ter diminuída sua própria oferta - para se ajustar a uma demanda muito distinta daquela existente anteriormente.

Entre 1963 e 1968 foram desativados: mais de 450 carros de passageiros (-13\% da frota); quase 1.400 vagões (- $4 \%$ da frota); e, 691 locomotivas movidas à vapor (redução de $60 \%$ na frota). No mesmo período em que a redução de passageiros transportados diminuiu $40 \%$ a quantidade de mercadorias transportadas cresceu 33\% (Relatórios da RFFSA).
4. Formalmente a origem da formação da FEPASA começa a partir de 1961, quando o Instituto de Engenharia de São Paulo, sugeriu a formação da RFP - Rede Ferroviária Paulista - sob controle estatal. Projetos de Lei foram encaminhados Assembleia Legislativa nos anos de 1962, 1966 e 1971. quando foi finalmente aprovado a formação da estatal ferroviária paulista (FEPASA 20 ANOS).

5. Fernando Collor de Mello, 15 de março de 1990 a 29 de dezembro de 1992; Fernando Henrique Cardoso, $1^{\circ}$. de janeiro de 1995 a $1^{\circ}$. de janeiro de 2003. 
Esta oferta menor de alguns de seus serviços, combinada com menor extensão das linhas e fortes investimentos em bens de capitais, implicou em menor demanda por empregados; logo em diminuição de custos que reduziriam parcialmente seus déficits. Destaque-se nesta fórmula o esforço da RFFSA, neste período analisado, em se tornar uma empresa genuinamente cargueira.

Portanto, a rigor não se pode afirmar que tenha ocorrido um desmonte generalizado das ferrovias brasileiras após a década de 1940, especialmente quando se compararam a produtividade média atingida em pelo menos em três momentos distintos daquelas linhas que pertenceram à RFFSA. Nesta empresa a produtividade média se tornou crescente, especialmente a partir do suposto "fim da era ferroviária"; se ampliando de algo em torno a 100 milhões de Unidades de Tráfego (UTs) por ano na década de 1950 para quase 600 milhões/ano em 1985; após a desestatização na década de 1990, quando ocorreu a erradicação dos transportes deficitários tais como o de passageiros de interior, bagagens e encomendas e animais, este indicador mais que dobrou, ao superar 1,7 bilhão UTs/ano (BRASIL, MVOP; Anuário Estatístico dos Transportes; Relatórios da RFFSA; ANTT).

Com base nestes indicadores pode-se afirmar que a RFFSA que foi ofertada em leilão na década de 1990 era uma empresa muito distinta daquela formada em 1957.

Quadro 1. RFFSA. Principais indicadores operacionais, $1961-1991$ (ano base $1961=100)$. Fonte: Relatórios da RFFSA.

\begin{tabular}{|c|c|c|c|c|c|}
\hline Anos & Linhas & P. interior (PKM) & P. subúrbio (PKM) & $\begin{array}{c}\text { Bagagens, encomendas } \\
\text { e animais (TKU) }\end{array}$ & Mercadorias (TKU) \\
\hline 1961 & 100,0 & 100,0 & 100,0 & 100,0 & 100,0 \\
\hline 1962 & 100,0 & 102,6 & 109,6 & 92,6 & 102,5 \\
\hline 1963 & 100,9 & 107,2 & 102,1 & 112,3 & 102,6 \\
\hline 1964 & 92,9 & 108,8 & 94,8 & 104,0 & 108,8 \\
\hline 1965 & 91,5 & 111,8 & 88,1 & 102,7 & 122,8 \\
\hline 1966 & 87,9 & 77,8 & 77,7 & 90,4 & 123,9 \\
\hline 1967 & 88,0 & 62,2 & 76,6 & 73,3 & 122,8 \\
\hline 1968 & 87,1 & 64,0 & 79,2 & 68,0 & 136,2 \\
\hline 1969 & 88,7 & 59,6 & 76,0 & 60,5 & 151,3 \\
\hline 1970 & 87,9 & 56,0 & 68,8 & 45,8 & 160,9 \\
\hline 1971 & 86,8 & 51,3 & 60,6 & 39,9 & 152,5 \\
\hline 1972 & 86,0 & 50,7 & 63,5 & 44,2 & 156,0 \\
\hline 1973 & 84,3 & 50,7 & 61,4 & 39,7 & 188,8 \\
\hline 1974 & 84,5 & 52,0 & 60,8 & 34,2 & 243,5 \\
\hline 1975 & 85,8 & 52,0 & 58,7 & 31,1 & 264,9 \\
\hline 1976 & 84,6 & 52,8 & 70,4 & 30,8 & 312,9 \\
\hline 1977 & 82,8 & 48,7 & 74,7 & 31,5 & 337,0 \\
\hline 1978 & 83,4 & 40,8 & 82,9 & 19,3 & 336,3 \\
\hline 1979 & 83,0 & 33,1 & 82,1 & 12,7 & 369,5 \\
\hline 1980 & 82,6 & 32,2 & 90,8 & 9,5 & 443,9 \\
\hline 1981 & 81,2 & 35,4 & 95,5 & 10,2 & 414,9 \\
\hline 1982 & 80,9 & 32,7 & 101,2 & 11,8 & 422,9 \\
\hline 1983 & 80,9 & 29,3 & 110,5 & 10,4 & 395,5 \\
\hline 1984 & 80,0 & 23,6 & 130,1 & 5,9 & 447,4 \\
\hline 1985 & 77,6 & 18,2 & 9,2 & 3,1 & 495,9 \\
\hline 1986 & 77,3 & 21,6 & 8,0 & 4,3 & 517,4 \\
\hline 1987 & 77,3 & 18,3 & 6,9 & 3,1 & 497,3 \\
\hline 1988 & - & 13,7 & 0,4 & 2,6 & nd \\
\hline 1989 & 77,5 & 9,9 & 0,3 & 2,0 & 501,9 \\
\hline 1990 & 77,2 & 8,7 & 0,4 & 1,6 & 461,1 \\
\hline 1991 & 77,2 & 7,7 & 0,3 & 1,4 & 485,8 \\
\hline
\end{tabular}


Conforme se pôde observar, a estrutura operacional havia se transformado muitíssimo. As linhas da companhia haviam se reduzido em mais de um quinto; os serviços de passageiros, de interior, equivaliam a menos de $8 \%$ do total realizado em 1961; o serviço de subúrbios, que desde 1984 havia sido transferido para a Companhia Brasileira de Trens Urbanos (CBTU) estava praticamente extinto, enquanto os transportes de bagagens, encomendas e animais já estavam, na prática, desativados. Diferentemente, no entanto, o transporte de mercadorias, que comparativamente a 1961 havia se expandido em mais de $385 \%$.

Definitivamente, os indicadores parecem não deixar margens às dúvidas de que a empresa havia passado por um longo período de reinvenção, e se convertido em uma empresa essencialmente cargueira. Ao se observar a produção comparativamente ao quadro de funcionários em serviço fica evidente a correlação entre a nova estrutura de transportes da RFFSA e a redução do quadro de funcionários - o que contribuiu decisivamente para a redução do déficit, que era crônico deste a década de 1940.

A quantidade de ferroviários em serviços tornou-se fortemente decrescente a partir de 1965 e o inverso passou a ocorrer com o total de mercadorias transportadas pela empresa. Entre 1964 e 1985 o total de empregados foi reduzido em mais de 55\% enquanto, como visto acima, a expansão dos transportes de mercadorias cresceu muitíssimo mais.

Vale destacar que simultaneamente a este aumento da produção, ocorreu uma forte especialização no rol das mercadorias transportadas. Na RFFSA, em 1984, por exemplo, apenas cinco mercadorias equivaliam a quase $70 \%$ do total de mercadorias transportadas pela companhia. Pode-se dizer, portanto, que quatro grupos de clientes dos respectivos setores de minérios, petróleo, siderúrgicos e cimento, tornaram-se responsáveis diretos por quase $70 \%$ da receita da empresa, naquele ano.

Quadro 2. RFFSA. Principais mercadorias transportadas, 1984. Fonte: BRASIL. Ministério dos transportes.

\begin{tabular}{|c|c|c|c|c|c|}
\hline & Mercadorias & TKU & \% TKU & Receita Cr\$ (x mil) & $\%$ Receita \\
\hline 1 & Minério de ferro & 12.305 .322 & 36,7 & $239.910 .539,0$ & 24,7 \\
\hline 2 & Derivados de petróleo & 3.890 .474 & 11,6 & $181.115 .768,0$ & 18,6 \\
\hline 3 & Produtos siderúrgicos & 2.957 .973 & 8,8 & $111.599 .419,0$ & 11,5 \\
\hline 4 & Cimento & 2.746 .804 & 8,2 & $61.328 .284,0$ & 6,3 \\
\hline 5 & Carvão mineral & 1.452 .803 & 4,3 & $67.328 .636,0$ & 6,9 \\
\hline & Subtotal & 23.353 .376 & 69,7 & $661.282 .646,0$ & 68,0 \\
\hline & RFFSA & 33.503 .137 & 100,0 & $972.912 .003,0$ & 100,0 \\
\hline
\end{tabular}

E, a título de comparação vale lembrar que no caso de outra empresa estatal, a Estrada de Ferro Vitória a Minas (EFVM), a especialização nos transportes de cargas tornara-se ainda maior. O fluxo de cargas nesta companhia quase dobrou entre 1964 e 1968. Quando se compara o período 1968 a 1973, verifica-se a expansão do transporte de cargas chegou a quintuplicar. Entre 1961 e 1984, a evolução deste total transportado chegou a mais de 1500\%; enquanto o transporte de passageiros cresceu em torno de 40\%, no mesmo período (Anuário Estatístico dos Transportes).

Ao final do período analisado a quantidade de ferroviários em serviço havia se reduzida a menos de um terço do total ocupado em 1961, passando de 152.462 trabalhadores em 1961 para 49.342 em 1991 (Relatórios da RFFSA) - o que parece não deixar margens a dúvidas de que o Estado submeteu a RFFSA a um longo processo de reestruturação produtiva. E, vale lembrar, esta reestruturação não se limitou apenas ao desmonte de linhas e ramais considerados antieconômicos ou ao corte de mão de obra. Em outros termos, não se limitou a 'desmontar' ou acabar com a RFFSA. 
Conforme se ensina nos manuais de Economia, para se obter aumento da produção necessita-se, obrigatoriamente, de investimentos em fator capital ou em trabalho. E o Estado brasileiro (durante os governos Fernando Collor de Melo e de Fernando Henrique Cardoso), muito investiu na malha estatizada; e isso vinha ocorrendo desde antes da formação da RFFSA. O primeiro contrato de financiamento patrocinado pelo BNDES, por exemplo, contemplando a Estrada de Ferro Central do Brasil, ocorreu em 10 de novembro de $1952 .{ }^{6}$ E muito mais deste recurso público continuou a ser investido na reconstrução da rede nos anos seguintes. Segundo Lacerda:

Entre 1956 e 2001, investiram-se R $\$ 55$ bilhões na RFFSA e R $\$ 14$ bilhões na CVRD. Os investimentos na RFFSA, após terem permanecido em $\mathrm{R} \$ 740$ milhões anuais entre 1956 e 1970, sofrem forte aceleração a partir de 1971, alcançando R \$4,4 bilhões em 1976. Nos anos seguintes os investimentos, apesar de ainda elevados, diminuem bastante, até voltarem, em meados dos anos [19]80, aos níveis dos [19]60. A grande elevação durante a década de 70 e o início da década seguinte reflete a política de investimentos do governo federal através do I e do II PND; já a posterior diminuição se relaciona ao estrangulamento fiscal do governo brasileiro a partir da crise da dívida externa, nos 80. Entre 1985 e 1993, o investimento médio anual da RFFSA é de R\$709 milhões. No período 1994-96, que precede a concessão da Rede a particulares, os investimentos diminuem ainda mais, para uma média anual de R \$70 milhões [em 1995, são de apenas R 18 milhões]. Após as privatizações, os investimentos voltaram a crescer, agora para $\mathrm{R} \$ 414$ milhões anuais ${ }^{7}$ (Lacerda, 2002: 354).

E os investimentos públicos não pararam por aí: ao ser liquidada, a RFFSA (ou seja, o conjunto das principais malhas férreas estatizadas no Brasil ao longo dos anos anteriores à formação desta) deixou para trás dívidas que segundo o Ministério do Planejamento, superam a vinte bilhões de reais: “dívidas de R \$ 14,984 bilhões (metade com o próprio governo) e passivo trabalhista de até R\$ 7,539 bilhões" (BRASIL, 29/09/2017; FOLHA DE SÃO PAULO, 25/01/2007).

Com base no exposto não chega a surpreender o fato de que a empresa passou a alcançar brutal aumento de produtividade média. Quando comparados os dois anos 1961 a 1991 verifica-se um acréscimo de algo em torno de $440 \%$ na produtividade média por trabalhador - que foi ampliada de 138,0 milhões de UTs para algo em torno a 746 Milhões de UTs/ano (Anuários Estatísticos da RFFSA). Portanto, entre 1961 e 1991 se altera o modelo de negócios ferroviários vigente desde o século XIX (baseado no conceito de "produção múltipla" - no qual as ferrovias eram obrigadas a "transportar todo a todas partes e en todo tiempo, con a regularidad obligada de sus servicios" (CENA, 2012:12).

Antes de ser ofertada em leilão a RFFSA a empresa já havia sido reformata passando a operar em um modelo de 'ferrovia-mínima' (ou, de “produção simples”), portadora das seguintes características.

Limitada em sua extensão quilométrica, restrita à sua porção mais produtiva, devido à erradicação de linhas e ramais considerados antieconômicos.

Desvinculada de serviços demandantes de mão de obra (leia-se deficitários) tais como os transportes de bagagens e encomendas, animais e passageiros de interior e os transportes de passageiros de subúrbio, que foram acomodados em empresas independentes da operação cargueira. ${ }^{8}$

Especializada em determinados segmentos de transportes de mercadorias com maior densidade e transportada a longa distâncias (portanto, com baixa demanda por mão de obra).
6. Os recursos se destinavam ao programa de reaparelhamento da ferrovia, elaborado com base no Projeto no. 3 da Comissão Mista Brasil-Estados Unidos (CMBEU). Entre 1954 e 1956, foram aprovados financiamento para diversas ferrovias, como a Estrada de Ferro de Goiás, a Rede de Viação Paraná-Santa Catarina, a Rede Ferroviária do Nordeste,

a Rede Mineira de viação e a

Estrada de Ferro Dona Tereza Cristina (LACERDA, 2002:351).

7. Valores expressos em reais, em termos constantes de 31 de dezembro de 2001 (idem, p. 349)

8. Da RFFSA, em 1984, surgiu a Companhia Brasileira de Trens Urbanos (CBTU). Em 1992, esta acabou se unificando com o transporte metropolitano operado pela Ferrovia Paulista S.A (FEPASA), o que deu origem à Companhia Paulista de Trens Metropolitanos (CPTM). 
Importante ter em mente que o déficit seguiu ocorrendo, mesmo depois deste forte rearranjo ocorrido na RFFSA após o Golpe civil-militar, em 1964. O déficit embora decrescente, especialmente entre 1965 e 1970, cessou, equilibrando a receita apenas em 1980. O saldo operacional superavitário somente passou a ocorrer a partir de 1984 - já em tempos de abertura política; período em que os trabalhadores já haviam retomado alguma iniciativa na luta contra a 'ditadura e o arrocho salarial' (Relatórios da RFFSA). Esse alto déficit, persistente até 1979 e debelado em tempos de abertura só atesta, portanto o equívoco daqueles que, como Cipollari (1978) e Santos (1961), argumentam que os resultados deficitários daquelas empresas que formaram a RFFSA, em 1957, estavam relacionados ao excessivo poder de barganha dos ferroviários no período democrático, compreendido entre o fim do Estado Novo (1945) e o Golpe civil-militar de 1964.

\section{As ferrovias mínimas: concessão pública, uso privado}

Durante o governo Collor ${ }^{9}$ iniciou-se, de fato e de direito, a estruturação de um novo modelo de negócios ferroviários, ao qual se pode denominar 'ferrovia-mínima. ${ }^{10}$ Efetivamente, a transferência de empresas públicas para a iniciativa privada começou a se concretizar a partir da Lei 8.031/90, de 12 de abril de 1990, e suas alterações posteriores, que instituiu o Programa Nacional de Desestatização (PND) a cargo do Conselho Nacional de Desestatização (CND), órgão decisório, e o Banco Nacional de Desenvolvimento Econômico e Social (BNDES) como gestor do Fundo Nacional de Desestatização. Pois, a partir daí o Programa recebeu outro impulso decisivo em direção às desestatizações do setor ferroviário por meio da inclusão da RFFSA no PND, em 10 de março de 1992 - juntamente com a Rede Federal de Armazéns Gerais Ferroviários S.A. (AGEF) e a Engenharia, Construções e Ferrovias S.A. (VALEC) (BRASIL, 1992).

Esta nova estrutura se concluiu poucos anos depois, durante o governo de Fernando Henrique Cardoso quando este reafirmou (BRASIL, 1997) os parâmetros traçados anteriormente pelo governo Collor, por meio das desestatizações de três grandes estradas de ferro: Vitória a Minas (EFVM) e Carajás (EFC), ambas já controladas e operadas desde 27/06/97 pela então, recém privatizada, Vale do Rio Doce, e, por fim, pela incorporação da Ferrovia Paulista S.A (FEPASA) à RFFSA em 18 de fevereiro de 1998 (BRASIL,1998).

Os primeiros leilões para a transferência do setor ferroviário iniciaram-se 1996, quando a maior parte das linhas da RFFSA foi concedida (de novo) aos seus respectivos concessionários privados. Antes, porém, suas linhas foram loteadas, pela ordem, em sete partes (Novoeste, Centro-Leste, Sudeste, Tereza Cristina, Sul, Nordeste, e Malha Paulista).

A RFFSA, às vésperas da desestatização era uma empresa com uma estrutura bastante diversificada; operada por meio de 12 unidades operacionais. Em Juiz de Fora estava concentrada mais de dois terços da força de trabalho; em apenas cinco unidades operacionais (Juiz de Fora, B. Horizonte, Curitiba, P. Alegre, Bauru), se realizava aproximadamente $92,5 \%$ de toda a produção da empresa, e justamente nestas unidades se observa a ocorrência dos maiores níveis de produtividade laboral. Em Juiz de Fora, por exemplo, a produtividade média por ferroviário chegava a 1.747 milhões de Unidades de Transportes (UTs), seguida por Curitiba e Belo Horizonte, onde se atingiam as respectivas marcas de 659 e 657 milhões de UTs. Algo bastante superior ao que ocorria em outras unidades, tais como São Paulo (172 milhões); Salvador (210 milhões), São Luís (82 milhões) ou Recife, onde a produtividade alcançava meros 63 milhões de UTs, em 1990 (Anuário Estatístico da RFFSA).
9. Fernando Collor de MeIlo, 15 de março de 1990 a 29 de dezembro de 1992. 10. Equivalente, conforme Santana e Ramalho (2003), com a emergência do mundo enxuto, no qual se observa um aumento da produtividade simultaneamente à redução do emprego do fator trabalho (Santana, e Ramalho, 2003). 
Desigualmente também era a forma como determinados setores se utilizavam mais proporcionalmente dos serviços daquela empresa. Esse uso da RFFSA para o atendimento de uns poucos setores/clientes fica explícito quando se observa o processo de especialização a que a companhia vinha sofrendo desde antes do processo de desestatização. No ano de 1990, por exemplo, a quantidade de transporte de minérios (de ferro, manganês, etc.) equivalia a pelo menos $43 \%$ de toda a produção (em TKU) da Rede; os derivados de petróleo, em segundo lugar, equivaliam a 13\% do total, enquanto o montante de transportes de produtos siderúrgicos equivalia a quase 8\% (Anuário Estatístico da RFFSA). Três setores empresariais, portanto, demandavam a quase dois terços de todo o trabalho realizado pela empresa. Uma separação (ainda que um tanto aleatória), por setor empresarial, considerandose mineração, petróleo, siderúrgico, cimenteiro, soja e trigo, indicaria que meia dúzia de setores demandava naquela ocasião a quase $90 \%$ de toda a produção (em TKU) da RFFSA.

Nas unidades operacionais da Rede, posteriormente denominadas Malha Sudeste, onde se constituiu a MRS Logística, apenas dois segmentos empresariais (mineração e siderurgia) demandavam mais de $90 \%$ de toda a produção daquela estatal; na unidade Centro Leste (posteriormente Ferrovia Centro Atlântica) quatro setores se utilizavam de mais de dois terços da produção (em TKU) da estatal; em toda a Malha Sul apenas meia dúzia de setores empresarias demandavam mais de três quartos (77\%) de toda a produção da companhia (idem).

E, no entanto, os maiores demandantes dos serviços não eram necessariamente os setores que mais contribuíam proporcionalmente com a formação da receita operacional da RFFSA. O que sugere que havia aberta rivalidade entre os grandes clientes por obtenção de fretes mais compensadores para si. O minério de ferro, por exemplo, embora demandasse mais de $40 \%$ de toda a produção (em TKU) da Rede, participava com pouco mais de $26 \%$ da receita operacional da companhia. Dentre os segmentos mais demandantes da operação da RFFSA podem ser considerados exceção (ou seja, os que contribuíam proporcionalmente mais com a formação da receita) o setor de combustíveis (petróleo e álcool) e outras mercadorias (justamente aquelas dos clientes relativamente menores) (ibidem).

Não é por acaso, portanto, que no momento em que a correlação de forças políticas e ideológicas se tornou hegemonicamente favoráveis às 'desestatizações' no aparelho de estado brasileiro os grandes usuários do setor ferroviário se tornaram também, desde a inclusão da RFFSA no PND, em 1992, os principais interessados no avanço delas. Conforme informava a Revista Ferroviária, em pleno auge do PND, em 1997:

Imediatamente, começam a surgir os primeiros sinais de interesse privado e os grandes clientes se inquietam. MBR (Minerações Brasileiras Reunidas) e CSN (Companhia Siderúrgica Nacional), os dois maiores clientes da Rede, rivais por anos na discussão de quem obtém fretes mais compensadores, colocam de lado suas diferenças e se transformam em catalisadores do processo de concessão, arregimentando parceiros e formando a massa crítica que daí para adiante só permite ao trem circular em um sentido: de volta à gestão privada (Revista Ferroviária, 1997:33).

Vale destacar que, os negócios destes grandes clientes "catalisadores do processo de concessão" (bem como de diversos outros clientes menores) dependiam diretamente dos serviços ferroviários. Com a 'privatização' em vista estava em jogo, portanto, também os interesses desses vários grupos empresariais (mineradoras, siderúrgicas, exportadores de soja, indústria de cimento, etc.), que, havia décadas, se utilizavam dos serviços ferroviários estatais. ${ }^{11} \mathrm{E}$, com as mudanças de controle da RFFSA os clientes (em geral) poderiam vir a correr o risco de que esse novo concessionário revisasse as tarifas de modo

11. Não por acaso que, após o processo de desestatização, a Agência Nacional de Transportes Terrestres, definiu enfim o conceito de "Usuário dependente": 0 usuário ou a pessoa jurídica que considere a prestação de serviço de transporte ferroviário de cargas indispensável à viabilidade de seu negócio (ANTT). 
oportunista (CASTRO, 2000:246), o que poderia implicar em dificuldades aos negócios daqueles grandes usuários ferroviários localizados estrategicamente próximos àquelas linhas.

A partir do processo de desestatização, no entanto, diversos deles tornaram-se controladores de parcela significativa das linhas. Assim, as unidades de Juiz de Fora e S. Paulo (denominadas inicialmente Malha Sudeste, e posteriormente MRS Logística) se tornaram controladas pelos seguintes grupos: CSN 27,83\%; MBR 20,00\%; Usiminas 19,92\%; Vale 19,26\%; Gerdau 2,37\%; e, demais acionistas 10,62\% restantes. As unidades de Belo Horizonte, Campos e Salvador, denominadas em um primeiro momento Malha Centro Leste e renomeadas Ferrovia Centro Atlântica após o processo de desestatização, tornaram-se controladas primeiramente pela Vale do Rio Doce e Companhia Siderúrgica Nacional, e posteriormente pela VLI Multimodal S. A. ${ }^{12}$ As unidades nordestinas Fortaleza, Recife e São Luís (Malha Nordeste e posteriormente Companhia Ferroviária do Nordeste e, a partir de 2008, Transnordestina Logística S/A. - TLSA) foram controladas pelos seguintes grupos: Companhia Siderúrgica Nacional, 56,92\%; VALEC, 31,96\%; BNDESPar, 4,17\%; BNDES, 5,62\%; e FINAME, 1,33\%. As unidades operacionais de Curitiba e Porto Alegre (inicialmente Malha Sul passou à denominação de América Latina Logística sendo controladas pela ALL Holding (América Latina Logística S. A.). ${ }^{13}$ A unidade operacional de Bauru denominada Malha Oeste durante o processo de desestatização passou posteriormente à denominação de Ferrovia Novoeste S.A; em 2002 foi fundida à Ferrovia Bandeirantes S.A. (Ferroban) e as Ferrovias Norte Brasil S.A. (Ferronorte), formando o Grupo Brasil Ferrovias (formado, então, pelas antigas FEPASA, Noroeste e a novíssima FERRONORTE). Em 2004, ocorreu uma cisão que criou a Nova Novoeste, controladora da Malha Oeste; dois anos depois, em maio de 2006, a Brasil Ferrovias foi fundida à América Latina Logística, através de operação de troca de ações entre os respectivos controladores. ${ }^{14}$ A pequena unidade de Tubarão, cujo principal produto transportado é o carvão mineral, produzido no sul do Estado de Santa Catarina, destinado à geração de energia termelétrica, passou após o processo de desestatização a denominar-se Ferrovia Tereza Cristina S.A, controlada pelos seguintes grupos: Santa Lúcia Concessões Públicas, Administração e empreendimentos Vason, e Apply comércio e empreendimentos (Fonte: Ferrovia Teresa Cristina, 2017).

Quanto aos resultados obtidos por estas empresas, a partir da desestatização, é que seguiu ocorrendo "mais do mesmo" em relação ao aumento da produtividade. A produção seguiu crescente, a partir de 1997 - cerca de 40\%, se comparados os anos de 1995 a 2002.

Quadro 3. Ex-RFFSA. Comparativo TKU (x milhões) 1995 a 2002. Fonte: Anuários Estatísticos da RFFSA; GEIPOT e ANTT.

\begin{tabular}{|l|c|c|c|c|c|c|c|}
\hline Concessionárias & $\mathbf{1 9 9 5}$ & $\mathbf{1 9 9 7}$ & $\mathbf{1 9 9 8}$ & $\mathbf{1 9 9 9}$ & $\mathbf{2 0 0 0}$ & $\mathbf{2 0 0 1}$ & $\mathbf{2 0 0 2}$ \\
\hline MRS & 20.370 & 20.551 & 21.220 & 22.212 & 26.830 & 27.370 & 29.431 \\
\hline ALL & 9.021 & 6.847 & 8.345 & 9.583 & 10.280 & 11.998 & 12.830 \\
\hline FCA & 6.866 & 5.275 & 7.019 & 7.429 & 7.620 & 8.143 & 8.608 \\
\hline Novoeste & 1.068 & 1.487 & 1.577 & 1.626 & 1.590 & 1.465 & 1.708 \\
\hline CFN & 767 & 515 & 640 & 919 & 710 & 700 & 757 \\
\hline FTC & 102 & 149 & 166 & 166 & 280 & 214 & 191 \\
\hline Total & 38.194 & 34.824 & 38.967 & 41.935 & 47.310 & 49.890 & 53.525 \\
\hline
\end{tabular}

No entanto, seguindo a tendência já observada desde os tempos da RFFSA, a quantidade de ferroviários em atividade seguiu decrescente - cerca de $75 \%$, se comparados os anos de 1995 a 2002.
12. A VLI Multimodal S.A. (antigo acrônimo para Valor da Logística Integrada) é uma empresa de logística do Brasil que controla as concessionárias de transporte ferroviário de cargas Ferrovia Centro-Atlântica S.A. (FCA) e Ferrovia Norte-Sul S.A. no trecho entre Açailândia e Palmas, totalizando 7.940 quilômetros de extensão. Opera também as ferrovias sob concessão da Vale: Estrada de Ferro Carajás e Estrada de Ferro Vitória a Minas. A VLI opera terminais de transbordo de grãos, como o Terminal Integrador de Araguari (TIA), e o Terminal Integrador de Palmeirante (TIPA). Opera também terminais no Porto do Itaqui, em São Luís; no Porto de Tubarão, em Vitória; no Porto da Barra dos Coqueiros, Terminal Marítimo Inácio Barbosa; e o Terminal Integrador Portuário Luiz Antônio Mesquita (TIPLAM), em Santos. (Fonte: VLI. Portos, ferrovias e terminais. Disponível em: <http://www.vli-logistica. com/pt-br/conheca\#sessa03>. Acessado em 24/o6/2017).

13. Com sede em Curitiba (PR), opera no Brasil em quatro concessões (ALL Malha Sul S.A., ALL Malha Oeste S.A., ALL Malha Paulista S.A. e ALL Malha Norte S.A.), que totalizam aproximadamente 13 mil $\mathrm{km}$ de ferrovias, o equivalente a $45 \%$ de toda a malha ferroviária do país. Entre os principais produtos transportados pela companhia estão commodities agrícolas (como milho, soja, farelo de soja e açúcar) e produtos industrializados. Esse segundo mercado é composto de dois segmentos: Produtos puramente ferroviários: combustíveis, óleo vegetal e materiais para a construção civil - tradicionalmente transportados por ferrovia no Brasil, mesmo antes do processo de privatização. Produtos intermodais: que incluem cargas que não têm histórico de utilização do transporte ferroviário no Brasil, mas que passaram a adotar o modal em função das melhorias realizadas nessas operações ao longo dos últimos anos. São elas: madeira, papel e celulose, produtos siderúrgicos, alimentos e contêineres (Fonte: América Latina Logística - ALL, 2017). 14. Ferrovia Novoeste S.A. Disponível em: <http://appwebz. antt.gov.br/relatorios/ferroviario/concessionarias2003/o9NOVOESTE.pdf>. 
Quadro 4. Ex-RFFSA. Comparativo de empregados nos anos 1995 a 2002. Fonte: Anuários Estatísticos da RFFSA; GEIPOT e ANTT.

\begin{tabular}{|l|c|c|c|c|c|c|c|}
\hline Concessionárias & $\mathbf{1 9 9 5}$ & $\mathbf{1 9 9 7}$ & $\mathbf{1 9 9 8}$ & $\mathbf{1 9 9 9}$ & $\mathbf{2 0 0 0}$ & $\mathbf{2 0 0 1}$ & $\mathbf{2 0 0 2}$ \\
\hline MRS & 9.398 & 3.928 & 3.299 & 3.093 & 2.988 & 2.741 & 2.709 \\
\hline ALL & 9.604 & 3.110 & 2.379 & 2.216 & 2.018 & 2.055 & 2.122 \\
\hline FCA & 10.988 & 3.249 & 2.416 & 2.296 & 2.590 & 2.821 & 2.582 \\
\hline Novoeste & 2.424 & 780 & 623 & 651 & 639 & 689 & 618 \\
\hline CFN & 3.886 & 969 & 622 & 614 & 694 & 939 & 946 \\
\hline FTC & 343 & 165 & 151 & 144 & 142 & 215 & 229 \\
\hline Total & 36.643 & 12.201 & 9.490 & 9.014 & 9.071 & 9.460 & 9.206 \\
\hline
\end{tabular}

O que implicou, visivelmente, em enorme aumento de produtividade média, que cresceu cerca $460 \%$ no mesmo período.

O que teria contribuído para esse elevado aumento da produção e produtividade?

Vale destacar que, segundo a lei de rendimentos decrescentes, haverá uma queda na produção marginal sempre que (mantido todo o mais constante) houver redução de um fator de produção - trabalho, por exemplo. $\mathrm{O}$ aumento da produção, em um cenário de forte redução da mão de obra parece, portanto, ter sido compensado pelo investimento em fator capital, combinado com o enxugamento das atividades que estes novos concessionários foram autorizados a realizar (especialmente com a desativação da modalidade de transportes de passageiros, de interior). Basicamente, esse prosseguimento do aumento da produtividade, parece ter vindo de ações de enxugamento (redução do 'tamanho' das empresas) combinadas com os investimentos realizados em fator capital (mais de R \$ 1,0 bilhão, entre 1997 e 2000) focados em substituição de locomotivas e vagões por veículos mais modernos.

Quadro 5. Ex-RFFSA. Investimentos realizados, 1996 a 2000 (Reais x mil). Fonte: Anuários Estatísticos da RFFSA; GEIPOT e ANTT.

\begin{tabular}{|l|c|c|c|c|c|c|}
\hline Concessionárias & $\mathbf{1 9 9 6}$ & $\mathbf{1 9 9 7}$ & $\mathbf{1 9 9 8}$ & $\mathbf{1 9 9 9}$ & $\mathbf{2 0 0 0}$ & Acumulado \\
\hline MRS - Logística & & 108.641 & 82.417 & 76.006 & 105.753 & 372.817 \\
\hline ALL & & 67.030 & 40.239 & 94.307 & 82.357 & 283.933 \\
\hline FCA & 19.028 & 49.198 & 59.647 & 53.918 & 89.767 & 271.558 \\
\hline Novoeste & 2.013 & 8.420 & 7.386 & 6.999 & 7.001 & 31.819 \\
\hline Malha Nordeste & & & 2.909 & 10.186 & 7.997 & 21.092 \\
\hline F. Tereza Cristina & & 3.668 & 4.034 & 3.862 & 6.142 & 17.706 \\
\hline FERROBAN & & 2.036 & 1.743 & 9.891 & 314 & 13.984 \\
\hline Total & 21.041 & 238.993 & 198.375 & 255.169 & 299.331 & 1.012 .909 \\
\hline
\end{tabular}

Grande parte da frota de antigas locomotivas recebidos da RFFSA acabou desativada. Quando se compara o total de locomotivas existentes em 1996, com o total que efetivamente entrou em operação, a partir de 1997, verifica-se que, nestes dois primeiros anos (1996-1997) a desativação chegou a atingir pelo menos um terço da frota total.

Quadro 6. Ex-RFFSA. Desativação de locomotivas. Comparativo 1996 e 1997. Fonte: Anuários Estatísticos da RFFSA; GEIPOT e ANTT.

\begin{tabular}{|l|c|c|c|c|c|}
\hline Ano & Locomotivas & ALL & FCA & MRS & RFFSA+FEPASA \\
\hline 1996 & Existentes & 839 & 398 & 390 & 2.047 \\
\hline 1997 & Efetivamente em tráfego & 557 & 231 & 268 & 1.359 \\
\hline & Redução em \% & 33,6 & 42,0 & 31,3 & 33,6 \\
\hline
\end{tabular}

Em linha com esta estratégia inicial, a recomposição da frota teve início já a partir de 1997 quando aquele conjunto foi aumentado de 1.015 locomotivas em serviço para 2.176, em 2004 (ANTT). O que resultou em crescimento da produtividade média 
destas locomotivas, neste período. Nos primeiros anos, imediatamente após a desestatização, a produtividade média subiu de 27,6 milhões de TKU para 40,9 milhões de TKU - algo em torno a $48 \%$, entre 1996 e $2000^{15}$ (idem).

No caso dos vagões, embora o conjunto das empresas analisadas, acima, contassem com aproximadamente 35.300 unidades, em 1996, passaram a utilizar efetivamente em tráfego, no ano seguinte, cerca de 29.000 unidades - o que equivaleu a uma desativação de pelo menos $18 \%$ da frota total. No caso da FCA, a empresa dispensava-se de usar cerca $29 \%$ desta frota; na MRS, este montante de vagões não utilizados chegou a cerca $20 \%$; na Novoeste, $7 \%$ da frota deixou de ser utilizada (GEIPOT).

Entre 1997 e 2000 verifica-se um acréscimo líquido, neste conjunto de empresas, de 2.200 vagões; puxado basicamente pela FCA que aumentou sua frota em mais de 2.800 vagões (após tê-la reduzido em quase 2.400 vagões, entre 1996 e 1997); e pela ALL, que acrescentou à sua frota cerca de 900 destes veículos, entre 1997 e 2000. Duas delas, chegaram a 2000, com menos vagões em operação em relação ao que havia em 1997: a Novoeste (-1.377 unidades) e a MRS (-179) (GEIPOT).

Por meio desta renovação ou racionalização da frota, embora se passasse a operar com uma quantidade parecida de vagões, verifica-se que estes se tornaram bem mais produtivos. Considerando-se apenas os primeiros anos após a desestatização, percebe-se que houve aumento da produtividade média dos vagões, que subiu de aproximadamente 0,7 milhão de TKU/ano para 1,3 milhão de TKU/ano - o que equivale a um aumento de pelo menos $91 \%$, entre 1996 e $2000^{16}$ (idem).

Por consequência, as receitas operacionais, formadas pelo conjunto dessas principais empresas (ALL, FCA e MRS) passaram a superar as despesas operacionais, voltando estas a categoria de empresas, enfim, depois de décadas de estatização, superavitárias, ao final da década de 1990. Aquele conjunto de empresas, deficitárias ao longo de décadas, pareciam ter, enfim, reencontrado o rumo da prosperidade. ${ }^{17}$

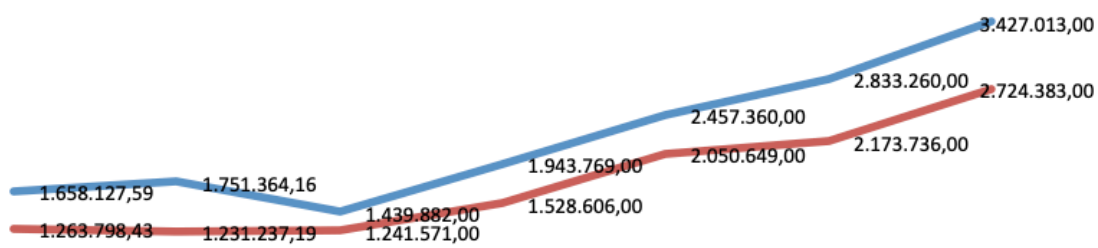

1999 2000

2001

2002

2003

2004

2005

Figura 6. Ex-RFFSA. Comparativo receita e despesa, 1999-2005. Fonte: ANTT. Ex-RFFSA: MRS; ALL: MS, MP e ALL-MO; FCA e MRS.

Quando se comparam os três períodos distintos: I) que antecede desestatização (1986-1992); II) imediatamente após a reconcessão privada (1997-2002), e III) compreendido entre cerca da metade e três quartos do período restante de concessão (2008 a 2016), verifica-se que neste último, diferentemente ao que ocorrera no segundo período, quando a produção havia crescido em torno de $57 \%$ (isso em um cenário de redução da mão de obra, em torno de 50\%), a produção passou a aumentar em um ritmo bem mais modesto: menos de $10 \%$, em um contexto
15. Vale destacar que após 2000 (ano em se atingiu 40,9 milhões de TKU/ano) a produtividade seguiu comparativamente maior; embora este desempenho não tenha seguido uniformemente crescente. Entre 2001 e 2004, por exemplo, se nota uma queda nesta tendência, que chegou a 34,3 milhões de TKU/ano, em 2004; em 2007 atingiu a marca de 53,3 milhões de TKU/ano - recuando para 41,9 milhões de TKU/ ano, em 2009; seguido de novo aumento até 2011 (47,3 milhões de TKU/ano, a partir do qual entrou em queda até 2015 (quando chegou a 42 milhões de TKU/ano); recuperando-se algo novamente, ao atingir 46,5 milhões/ano em 2016 - mesmo nível obtido em 2010. No entanto, se considerados apenas o ano em que se inicia a desestatização (1996) com o último ano analisado (2016), a diferença chega a $68,5 \%$. (Fonte: Anuários Estatísticos da RFFSA; GEIPOT e ANTT).

16. Parece evidente que este aumento de produtividade esteve diretamente relacionado às iniciativas já apontadas; e tal, comportamento crescente a partir daí, não tem sido isento de percalços. Entre 2001 e 2005, por exemplo, se verifica uma queda nesta produtividade, que chegou 0,9 milhão de TKU, em 2005, voltando a subir entre 2005 e 2007 , seguido de queda em 2008 e 2009; a parti daí, em viés de alta, atingiu o pico em 2013 (1,9 milhão de TKU/ano), mantendo-se perto deste nível até 2016. A título de comparação, se considerados apenas o ano de 1996 com o último ano analisado (2016), a diferença chega a 175\% (Fonte: Fonte: Anuários Estatísticos da RFFSA; GEIPOT e ANTT).
17. Vale ponderar que este resultado apresentado representa a média do conjunto das principais empresas que compunham a RFFSA, ao final da década de 1990 (FEPASA, inclusive). Tanto a ALL (Malha Sul) quanto a MRS (Malha Sudeste) apresentaram superávits em todo o período 1999 a 2005 (37,9 e 42,2\% em relação à receita, respectivamente); dentre as deficitárias no período ficaram a FCA $(-2,2 \%)$ e as outras duas malhas operadas pela holding ALL: Malha Oeste $(-19,9 \%)$ e a Malha Paulista (-99,9\%); ainda assim, no conjunto, a ALL apresentou superávit médio de $4,7 \%$, no período. 
em que aquelas empresas voltaram a demandar proporcionalmente mais mão de obra (pelo menos 30\%, comparativamente ao período anterior), conforme se pode observar na Quadro 1.

Quadro 7. Ex-RFFSA*. Comparativos I, II e III: Produção, mão de obra ocupada e produtividade. Fonte: RFFSA, GEIPOT e ANTT. Ex-RFFSA*: No período 1986 a 1991, não está contida a antiga FEPASA/Ferroban/ ALL Malha Paulista, incorporada à RFFSA em 1998.

\begin{tabular}{|l|c|c|c|c|c|}
\hline Anos & $\begin{array}{c}\text { Produção } \\
\text { (TKU x mil) }\end{array}$ & Ferroviários & $\begin{array}{c}\text { Produtividade } \\
\text { média (milhões) }\end{array}$ & $\begin{array}{c}\text { Produção } \\
\text { (\%) }\end{array}$ & $\begin{array}{c}\text { Ferroviários } \\
\text { (\%) }\end{array}$ \\
\hline 1986 & 38.767 .769 & 63.878 & 606,9 & 100,0 & 100,0 \\
\hline 1987 & 37.263 .906 & 62.829 & 593,1 & 96,1 & 98,4 \\
\hline 1988 & 37.436 .435 & 60.639 & 617,4 & 96,6 & 94,9 \\
\hline 1989 & 37.608 .963 & 58.449 & 643,4 & 97,0 & 91,5 \\
\hline 1990 & 34.552 .541 & 52.976 & 652,2 & 89,1 & 82,9 \\
\hline 1991 & 36.402 .433 & 49.342 & 737,8 & 93,9 & 77,2 \\
\hline Média I & 37.005 .341 & 58.019 & 637,8 & 95,5 & 90,8 \\
\hline 1997 & 39.389 .000 & 22.050 & $1.786,3$ & 100,0 & 100,0 \\
\hline 1998 & 41.755 .000 & 15.929 & $2.621,3$ & 106,0 & 72,2 \\
\hline 1999 & 46.971 .000 & 12.070 & $3.891,5$ & 119,2 & 54,7 \\
\hline 2000 & 53.730 .000 & 12.245 & $4.387,9$ & 136,4 & 55,5 \\
\hline 2001 & 58.166 .800 & 13.304 & $4.372,1$ & 147,7 & 60,3 \\
\hline 2002 & 61.833 .000 & 11.531 & $5.362,3$ & 157,0 & 52,3 \\
\hline Média II & 50.307 .467 & 14.522 & $3.464,3$ & 127,7 & 65,9 \\
\hline 2008 & 93.591 .000 & 20.168 & $4.640,6$ & 100,0 & 100,0 \\
\hline 2009 & 87.930 .000 & 24.848 & $3.538,7$ & 94,0 & 123,2 \\
\hline 2010 & 96.984 .000 & 27.403 & $3.539,2$ & 103,6 & 135,9 \\
\hline 2011 & 100.631 .000 & 29.609 & $3.398,7$ & 107,5 & 146,8 \\
\hline 2012 & 102.015 .000 & 27.092 & $3.765,5$ & 109,0 & 134,3 \\
\hline 2013 & 101.798 .000 & 27.107 & $3.755,4$ & 108,8 & 134,4 \\
\hline 2014 & 103.740 .000 & 27.535 & $3.767,6$ & 110,8 & 136,5 \\
\hline 2015 & 105.315 .000 & 28.061 & $3.753,1$ & 112,5 & 139,1 \\
\hline Média III & 99.000 .500 & 26.478 & $3.769,9$ & 105,8 & 131,3 \\
\hline & & & & & \\
\hline
\end{tabular}

O máximo da produtividade média, obtido entre 1997 e 2002, havia ficado para trás, quando neste último ano se atingiu o recorde de produtividade de 5,3 milhões de TKU/ ferroviário ano. $^{18}$

Ao se tomar o ano 2002 como referência verifica-se ter ocorrido em 2009 e 2010, respectivamente, uma redução de $34 \%$ na produtividade média; em 2011, essa diminuição teria alcançado a 37\%; se comparados aos anos compreendidos entre 2012 e 2015, a produtividade chegou a cair algo próximo a 30\%. E essa queda de produtividade por parte das concessionárias, parece acompanhar a redução (2005-2006; 2008-2009; 2011-2015) no nível de investimentos por parte das concessionárias, que em ritmo de espera, segundo matéria publicada no Estado de São Paulo, aguardavam definição do governo quanto à renovação das concessões.

No mercado, a renovação das concessões é vista como a saída mais natural. Mas é preciso fazer o processo de uma forma transparente e sem atropelos. "No caso das ferrovias, o primeiro contrato de concessão foi feito com uma série de falhas, que permitiu o sucateamento da malha nacional. Agora o governo [Temer] tem a chance de melhorar esses contratos", afirma uma fonte em Brasília. O problema está no caso da recuperação de trechos sucateados, que custa muito caro. Pela lei, se não tiverem interesse em investir nessa malha, as empresas teriam de indenizar o governo, o que também custaria caro. "Mas se não resolverem isso agora, não resolvem nunca mais", diz um especialista no setor que prefere não se identificar (O ESTADO DE SÃO PAULO, 24/10/2016).
18. E prosseguiu menor a partir de $2003(5,1), 2004(5,0), 2005(4,5)$, 2006 (4,7 e 2007 (4,6 milhões de TKU/ferroviário ano). (idem). 
Não por acaso que, em menos de dois meses após o controvertido 'afastamento' da presidente Dilma Roussef, o presidente Michel Temer tenha assinado, segundo a Revista Ferroviária "a tão esperada Medida Provisória que trata das concessões de ferrovias, rodovias, portos e aeroportos". De acordo com esta fonte, a MP 752, publicada no Diário Oficial da União de 25/10/2016, estabelece metas de produção e de segurança para a prorrogação antecipada dos contratos de concessão ferroviárias (Revista Ferroviária, 2017). Estes e outros motivos, parecem explicar um pouco o comportamento declinante dos investimentos entre 2011 a 2015.

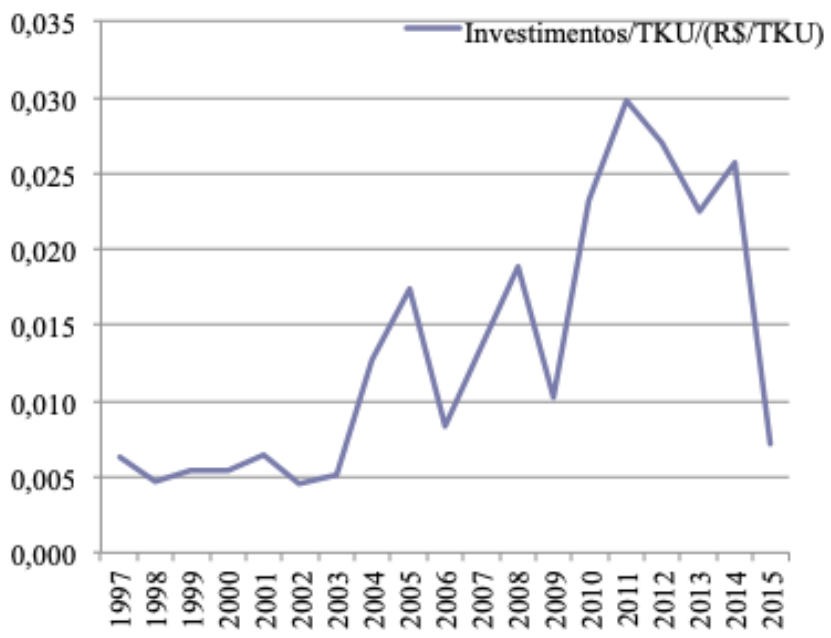

Figura 7. Ex-RFFSA. Investimentos realizados, 1997 a 2015 (R\$̦/TKU). Fonte: ANTT.

Outro tema pendente, neste debate a envolver a renovação da concessão, refere-se aos trechos sucateados que não mais interessam (ou que na verdade nunca foram interessantes aos novos concessionários). Desde 2013, tem se tornado explícito que parcela significativa das linhas concedidas na década de 1990 encontra-se subaproveitada ou não utilizada.

Segundo a Associação Nacional dos Usuários do transporte de Carga (ANUT), o poder concedente, (ANTT), já reconhece que pelo menos 5.544 quilômetros de vias se encontram subaproveitadas, ${ }^{19}$ nas seguintes malhas, a saber, (pela ordem de concessão): ALL-Malha Oeste (antiga NOVOESTE), 309 km; Ferrovia Centro Atlântica, 1.246 km; ALL-Malha Sul, 1.716 km, Transnordestina Logística, 1.623 km e ALL-Malha Paulista (ex-FEPASA), $650 \mathrm{~km}$.

Assim, após duas décadas, são agora os concessionários privados que recorrem ao Estado para reajustar o modelo solicitando basicamente mais do mesmo: mais "ferrovia-mínima”. Segundo a Revista Ferroviária, em algumas ferrovias, como é o caso da FCA as linhas se reduziram em quase $50 \%{ }^{20}$ por considerar que alguns de seus trechos ferroviários não atendiam mais às atuais necessidades dos usuários do transporte ferroviário; por não serem mais relevantes para o novo modelo da malha ferroviária brasileira. E, tal qual se dera no passado, tais trechos "considerados antieconômicos foram devolvidos ao Estado, e recebidos pelo Departamento Nacional de Infraestrutura de Transportes (DENIT), em 28 de agosto de 2013" (Revista Ferroviária, fevereiro/março de 2014:28).

No entanto, esse modelo ferrovia-mínima, parece ser mais ágil para ajustar seus fatores de produção à demanda. Contratações e demissões de trabalhadores (+9.441, entre 2008 e 2011; e -2.091, entre 2011 e 2016); aumento da frota de locomotivas (+462 entre 2008
19. Algo em torno a $21 \%$ daquelas linhas concedidas na década de 1990, considerando-se que os seis lotes (da RFFSA) concedidos mediam cerca de $26.600 \mathrm{~km}$.

20. Com base na Resolução $n$. 4131 a ANTT autoriza a desativação e a devolução de 3.989 $\mathrm{km}$ de trechos em seis Estados: BA, SE, MG, ES, RJ, SP. 
e 2015) ampliação e redução de vagões (+9.018 vagões entre 2008 e 2012 e redução de 9.252 unidades entre 2012 e 2016; o que indica provável movimento de renovação da frota) parecem indicar a flexibilidade que estas empresas passaram a desfrutar depois da desestatização (ANTT).

Flexibilidade que parece ter possibilitado ao conjunto das empresas (ex-RFFSA) ajustar a quantidade de trabalhadores. Assim, ora se amplia o quadro de pessoal, ora os substitui por fator capital (locomotivas e vagões), de acordo com a conveniência empresarial, sempre com vistas a garantir (mesmo ocorrendo redução da produtividade dos ferroviários) resultados para o capital investido no setor.

Conforme se pode observar os saldos das receitas parecem seguir cobrindo, a contento, as despesas operacionais, que na média estiveram próximas a $54 \%$ das receitas.

Quadro 8. ex-RFFSA. Saldo em relação à receita total: 2008-2013. Fonte: ANTT

\begin{tabular}{|l|c|c|c|c|c|}
\hline & Receita & Despesas & Pessoal & Saldo \% & $\begin{array}{c}\text { Salário/ } \\
\text { Despesa (\%) }\end{array}$ \\
\hline 2008 & $6.633 .459,00$ & $3.445 .009,00$ & $420.253,00$ & 51,9 & 12,2 \\
\hline 2009 & $5.363 .586,00$ & $2.952 .729,00$ & $408.118,00$ & 55,1 & 13,8 \\
\hline 2010 & $5.738 .986,00$ & $3.307 .308,00$ & $512.443,00$ & 57,6 & 15,5 \\
\hline 2011 & $6.688 .794,00$ & $3.627 .511,00$ & $568.349,00$ & 54,2 & 15,7 \\
\hline 2012 & $6.760 .180,00$ & $3.603 .134,00$ & $705.508,00$ & 53,3 & 19,6 \\
\hline 2013 & $7.423 .448,00$ & $3.778 .525,00$ & $690.566,00$ & 50,9 & 18,3 \\
\hline
\end{tabular}

Já a participação dos salários não chegou, pelo visto, a representar nem mesmo um quinto das despesas operacionais das companhias (ANTT).

Com base nestes e outros indicativos parece não haver dúvidas de que o setor ferroviário nacional deixou para trás aquele antigo padrão de funcionamento que vigia desde o século XIX, e passou a funcionar sob outra lógica: a da ferrovia-mínima, na qual os custos salariais, comparativamente aos custos de outras rubricas das empresas ferroviárias brasileiras do século XXI, tornam-se praticamente custos marginais.

\section{Considerações finais}

Buscou-se neste trabalho realizar uma apresentação panorâmica a respeito do funcionamento do sistema ferroviário brasileiro. De acordo com a metodologia aqui empregada o histórico do sistema ferroviário nacional deve ser entendido a partir das distintas fases que foram ajustando o funcionamento deste sistema de transportes, de tal modo a modificar profundamente os papeis do Estado, da gestão, do perfil dos produtos e clientes; bem como no modo de organização e utilização da força de trabalho.

A abordagem é eminentemente revisionista em relação às argumentações bastante conhecidas segundo às quais o sistema ferroviário brasileiro havia sido desmontado em ao final da década de 1940 .

O que se sustentou neste trabalho é que, a partir de 1961 encerrou-se o formato de modelo de negócios vigente no país desde o século XIX, no qual conviviam os setores públicos e privados. Diga-se de passagem, com forte presença estatal desde o início do século XX, numa porção acima daquela observada por Bogart, em sua amostra de trinta e cinco países. Essa tendência, de maior participação estatal ficou ainda maior após a Primeira Guerra Mundial e chegou a quase totalidade após o imediato pósSegunda Guerra. 
A partir de 1961, se observa é um processo, sem volta até o presente, de paulatina transferência do controle operacional desta infraestrutura para usos cada vez mais privados. E, conforme se pôde constatar, esse movimento de apropriação privada teve origem bem antes da abertura do processo de desestatização iniciada no governo Collor. Na verdade, a RFFSA já vinha há anos passando por um processo de desvinculação de linhas e serviços considerados deficitários - especialmente dos transportes de passageiros de subúrbios, a partir de 1984 - e por uma especialização no transporte de mercadorias - de algumas poucas mercadorias, de alguns poucos grandes usuários.

As malhas férreas entregues à 'privatização' na década de 1990 bem pouco lembravam as ferrovias altamente deficitárias da década de 1950. O fato inequívoco desta reinvenção, em que o setor passou a operar com base em uma lógica de "ferrovia-mínima", parece ser corroborado por um dado factual incontestável: os empresários (privados) voltaram ao setor! Para um setor, pelo visto, bastante remunerativo, em que a produtividade aumenta há décadas enquanto os salários vão se convertendo, praticamente, em custos marginais. 


\section{Q Bibliografía}

"Agência Nacional de Transportes Terrestres. (2015). Ferrovias. ANTT. Disponível em: <http://portal.antt.gov.br/index.php/content/view/4751/Ferroviaria.html>. Acesso em 23/06/2017.

» Anuário Estatístico dos Transportes. Ministério dos Transportes. Assessoria de Planejamento, Orçamento e Serviço de Estatística dos Transportes.

» Associação Nacional dos Transportdores Ferroviários (ANTF). Disponível em: http://www.antf.org.br/historico/. Acesso em 04/03/2018.

»Bogart, D. (2009). Nationalizations and the development of transport systems: Cross-country evidence from railroad networks, 1860-1912. The Journal of Economic History 69 (1), 202-237.

" Brasil, Ministério da Viação e Obras Públicas. Estatística das Estradas de Ferro relativa ao ano de 1952. Rio de Janeiro: Departamento Nacional de Estradas de Ferro, 1956.

" Brasil. Lei n. 2.698, de 27 de dezembro de 1955. Dá aplicação à receita proveniente da diferença de preços entre os combustíveis e lubrificantes líquidos derivados do petróleo fabricados no Brasil e importados, e altera o item II do $\S 2^{\circ}$ e o $\S 5^{\circ}$ do art. $9^{\circ}$ da Lei $n^{\circ} 2.145$, de 29 de dezembro de $1953 \mathrm{e}$ o $\S 1^{\circ}$ do art. $2^{\circ}$ da Lei $n^{\circ} 1.749$, de 28 de novembro de 1952, acrescentandoIhe um parágrafo. Diário Oficial da União - Seção 1 - 30/12/1955, Página 23873 (Publicação Original). Disponível em: <http://www2.camara.leg.br/legin/fed/ lei/1950-1959/lei-2698-27-dezembro-1955-355007-publicacaooriginal-1-pl.html>. Acesso em 28/02/2018.

" Brasil. Ministério Da Viação E Obras Públicas (MVOP). Estatística das Estradas de Ferro da União e das fiscalizadas pela União relativa ao anno de 1912. Rio de Janeiro: Imprensa Nacional, 1915.

» Brasil. Ministério Da Viação E Obras Públicas (MVOP). Estatística das Estradas de Ferro da União e das fiscalizadas pela União relativa ao anno de 1922. Rio de Janeiro: Imprensa Nacional, nd.

"Brasil. Ministério Da Viação E Obras Públicas (MVOP). Estatística das Estradas de Ferro da União e das fiscalizadas pela União relativa ao anno de 1936. Rio de Janeiro: Imprensa Nacional, 1938.

»Brasil. Ministério dos Transportes. Inventariança da extinta Rede Ferroviária Federal S/A.

» Brasil. Presidência da República Federativa do Brasil. LEI No 3.115, de 16 de março de 1957. Determina a transformação das empresas ferroviárias da União em sociedades por ações, autoriza a constituição da Rede Ferroviária S.A., e dá outras providências. Disponível em: <http://www.planalto.gov.br/ccivil_03/ leis/l3115.htm>. Acesso em 20 de janeiro de 2018.

» Brasil. Presidência da República. Decreto n. 2.502 de 18 de fevereiro de 1998. Autoriza a incorporação da Ferrovia Paulista S.A. - FEPASA pela Rede Ferroviária Federal S.A. - RFFSA e dá outras providências. Disponível em: <http://www. planalto.gov.br/ccivil_03/decreto/D2502.htm>. Acessado em 23/06/2017.

"Brasil. Presidência da República. Decreto n. 473, de 10 de março de 1992. Dispõe sobre inclusão, no Programa Nacional de Desestatização - PND, da Rede Ferroviária 
Federal S.A. - RFFSA, da AGEF - Rede Federal de Armazéns Gerais Ferroviários S.A. e da VALEC - Engenharia, Construções e Ferrovias S.A. Disponível em: <http:// www.planalto.gov.br/ccivil_03/leis/L8031.htm>. Acessado em 23/06/2017.

»Brasil. Presidência da República. Lei n. 9.491 de 9 de setembro de 1997. Altera procedimentos relativos ao Programa Nacional de Desestatização, revoga a Lei $n^{\circ}$ 8.031, de 12 de abril de 1990, e dá outras providências. Disponível em: <http:// www.planalto.gov.br/ccivil_03/leis/L9491.htm>. Acessado em 23/06/2017.

» Brasil. Presidência da República. LEI no. 8.031, de 12 de abril de 1990. Cria o Programa Nacional de Desestatização e dá outras providências. Disponível em: <http://www.planalto.gov.br/ccivil_03/leis/L8031.htm>. Acessado em 23/06/2017.

"Castro, N. de. (2017). Privatização do setor de transportes no Brasil. Disponível em: $<$ https://www.bndes.gov.br/SiteBNDES/bndes/bndes_pt/Galerias/Convivencia/ Publicacoes/Consulta_Expressa/Setor/Transporte/200002_9.html>. Acesso 2/ dezembro/2017.

»Cena, J. C. (2012). Ferrocarriles Argentinos: Destrucción/Recuperación. Buenos Aires: La Nave de los Locos, 2012.

»Cipollari, P., Garcia, M. E.; Carmo, H. C. E. do (1978). Emprego, salário e produtividade nas ferrovias brasileiras. Brasília - São Paulo: Conselho Nacional de Política de Emprego - Fundação Instituto de Pesquisas Econômicas (FIPE). Disponível em: <http://www.rffsa.gov.br/>. Acesso em 29/og/2017.

»Estrada De Ferro D. Pedro II. As estradas de ferro do Brasil em 1879 - primeira parte. Estrada de ferro nas províncias do Rio de Janeiro, Minas Geraes e S. Paulo. Rio de Janeiro: Typografia Nacional, 1880.

» FEPASA 20 Anos - Revista Comemorativa do 20ํaniversário da FEPASA. Três Editorial Ltda. São Paulo, 1991.

" MATOS, Odilon Nogueira de. Café e ferrovias. A evolução ferroviária de São Paulo e o desenvolvimento da cultura cafeeira. 4a. ed. Campinas: Pontes, 1990.

"Ferrovia Teresa Cristina. Disponível em: <http://ftc.com.br/a-empresa/ historia>. Acessado em 15/06/2017).

»Folha de São Paulo. Estatal ferroviária deixa rombo de R\$ 20 bilhões. Caderno Dinheiro, 25/01/2007. Disponível em: <http://www1.folha.uol.com.br/folha/ dinheiro/ult91u113995.shtml>. Acessado em 29/09/2017.

" GEIPOT. Empresa Brasileira de Planejamento de Transportes. Capítulo 4 Transporte Ferroviário. Disponível em: <http://www.geipot.gov.br/NovaWeb/ IndexAnuario.htm>. Acesso em 20/12/2017.

» Lacerda, S. M. (2002). O transporte ferroviário de cargas. Rio de Janeiro: BNDES. Disponível em: <https://web.bndes.gov.br/bib/jspui/bitstream/1408/12976/3/ BNDES\%2050\%20anos\%20-\%20Hist\%C3\%B3rias\%2oSetoriais_O\%20 transporte\%2oferrovi\%C3\%A1rio\%2ode\%20cargas_P.pdf>. Acesso em 29/09/2017.

"Nunes, I. (2017). Déficit e emprego ferroviário no Brasil, 1948-1963. In: XII Congresso Brasileiro de História Econômica e 13a. Conferência Internacional de História de Empresas. Niteroi, 28, 29 e 30 de agosto de 2017. Disponível em: <http://www.abphe.org.br/uploads/ABPHE\%202017/43\%20Deficit\%20e\%20 nivel\%20de\%2oemprego\%2oferroviario\%2ona\%2osegunda\%2ometade\%20 do\%2oseculo\%20XX.pdf>. Acesso em 20/12/2017.

»Revista Ferroviária. (2017). Os empresários e as ferrovias. Rio de Janeiro: Empresa 
Jornalística de Transportes, 1940-, mensal. Rio de Janeiro: Empresa Jornalística dos Transportes, abril 1997 (Suplemento).

»Revista Ferroviária. Publicada a MP das concessões. Disponível em: http:// revistaferroviaria.com.br/index.asp? InCdEditoria $=1 \& \operatorname{lnCdMateria~}=25398$. Acessado em 20/06/2017.

»RFFSA. Anuário Estatístico da RFFSA. Rio de Janeiro: Departamento de estatística e documentação. Anos diversos.

» RFFSA. Anuário estatístico da RFFSA. Rio de Janeiro: Depto de estatística e documentação, 1963.

"RFFSA. Plano de reaparelhamento. In: Relatório relativo ao ano de 1963. Rio de Janeiro, 1964.

»RFFSA. Relatório anual, 1964. Rio de Janeiro: Depto de estatística e documentação, 1965.

»Santana, M. A., Ramalho, J. R. (2003). Trabalhadores, sindicatos e a nova questão social. In: Além da fábrica. São Paulo, Boitempo.

"Santos, R. R. dos (1961). A crise das ferrovias. São Paulo: Jornal 'O Estado de São Paulo', 1961. (Série de 12 artigos publicados pelo Jornal O Estado de São Paulo entre 25 de abril a 10 de maio de 1961, "com o objetivo de mostrar à opinião pública o caos que se encontram os nossos transportes ferroviários").

\section{Ivanil Nunes / profivanilnunes@gmail.com}

Formado em Ciências Sociais, com Mestrado em Economia; Doutorado e pós-DOCs no campo das Ciências Sociais Aplicadas. Professor no ensino superior desde 2002, em instituições públicas e privadas no campo da Economia (Brasileira; Introdução à Economia; História Econômica). 